\title{
The Id-protein family in developmental and cancer-associated pathways
}

\author{
Cornelia Roschger and Chiara Cabrele ${ }^{*}$ (D)
}

\begin{abstract}
Inhibitors of DNA binding and cell differentiation (Id) proteins are members of the large family of the helix-loophelix $(H L H)$ transcription factors, but they lack any DNA-binding motif. During development, the Id proteins play a key role in the regulation of cell-cycle progression and cell differentiation by modulating different cell-cycle regulators both by direct and indirect mechanisms. Several Id-protein interacting partners have been identified thus far, which belong to structurally and functionally unrelated families, including, among others, the class I and II bHLH transcription factors, the retinoblastoma protein and related pocket proteins, the paired-box transcription factors, and the S5a subunit of the $26 \mathrm{~S}$ proteasome. Although the HLH domain of the Id proteins is involved in most of their protein-protein interaction events, additional motifs located in their $\mathrm{N}$-terminal and C-terminal regions are required for the recognition of diverse protein partners. The ability of the Id proteins to interact with structurally different proteins is likely to arise from their conformational flexibility: indeed, these proteins contain intrinsically disordered regions that, in the case of the HLH region, undergo folding upon self- or heteroassociation. Besides their crucial role for cell-fate determination and cell-cycle progression during development, other important cellular events have been related to the Id-protein expression in a number of pathologies. Dysregulated Id-protein expression has been associated with tumor growth, vascularization, invasiveness, metastasis, chemoresistance and stemness, as well as with various developmental defects and diseases. Herein we provide an overview on the structural properties, mode of action, biological function and therapeutic potential of these regulatory proteins.
\end{abstract}

Keywords: Id protein, Helix-loop-helix protein, Intrinsically disordered protein, Cell-cycle regulation, Cell differentiation, Development, Chemoresistance, Cancer stemness

\section{Background}

The helix-loop-helix $(\mathrm{HLH})$ transcription factors are a large family of proteins that share a common HLH domain for protein-protein interaction. They may be further divided in seven classes (Table 1) [1-3]: class I proteins are broadly expressed and contain an additional basic DNA-binding motif N-terminal to the HLH domain, thus they are called basic-HLH (bHLH) proteins. Examples of class I bHLH transcription factors are the $\mathrm{E}$ proteins (E12, E47, HEB and E2-2, also known as transcription factor 4 , abbreviated as TCF-4, or immunoglobulin transcription factor 2, abbreviated as ITF-2 [4]). The $\mathrm{E}$ proteins can form DNA-binding homodimers or heterodimers with other E proteins and class II bHLH proteins like the tissue-specific myogenic regulatory

\footnotetext{
* Correspondence: chiara.cabrele@sbg.ac.at

Department of Molecular Biology, University of Salzburg, Billrothstrasse 11, Salzburg 5020, Austria
}

(c) The Author(s). 2017 Open Access This article is distributed under the terms of the Creative Commons Attribution 4.0 International License (http://creativecommons.org/licenses/by/4.0/), which permits unrestricted use, distribution, and reproduction in any medium, provided you give appropriate credit to the original author(s) and the source, provide a link to the Creative Commons license, and indicate if changes were made. The Creative Commons Public Domain Dedication waiver (http://creativecommons.org/publicdomain/zero/1.0/) applies to the data made available in this article, unless otherwise stated. the bHLH domain is C-terminally elongated, respectively, with a leucine-zipper (LZ) motif [2, 7-11] and a Per-ARNT-SIM (PAS) motif [12]. Class VI proteins contain proline residues in the DNA-binding motif $[2,13,14]$. Finally, class V HLH proteins are the inhibitors of DNA binding and cell differentiation (Id1-4) that display no DNA-binding motif [15-17].

The HLH domain, which consists of two amphipatic $\alpha$-helices connected by a loop, is responsible of the homo- or heterodimerization of the (b)HLH proteins: the resulting fold is a non-covalent, parallel, left handed four-helix bundle $[5,18]$. In the case of bHLH dimers, such fold allows the tweezers-like juxtaposition of the two $\mathrm{N}$-terminal basic helices, which is ideal to specifically bind DNA double strands including E-boxes (CANNTG) [19-21], Nboxes (CACNAG) [14], and Ets sites (GGAA/T) [22] 
Table 1 Class I-VII of the HLH transcription factors

\begin{tabular}{|c|c|c|c|}
\hline Class & $\begin{array}{l}\text { Structural } \\
\text { domain }\end{array}$ & Representative members & Properties and function \\
\hline I & $\mathrm{bHLH}$ & E-protein family (E12, E47, E2-2/TCF-4/ITF-2, HEB) $[1-3,333]$ & $\begin{array}{l}\text { Broadly expressed; Self- or heteroassociation with class II proteins; } \\
\text { Regulation of neuro-, myo-, lymphogenesis }\end{array}$ \\
\hline$\|$ & $\mathrm{bHLH}$ & $\begin{array}{l}\text { Myogenic regulatory factors (MyoD, myogenin, Mrf4, Myf- } \\
\text { 5,6) [6]; NeuroD/Beta2 [334]; Mash-1 [335, 336], d/e-HAND } \\
\text { [337]; Twist [338] }\end{array}$ & $\begin{array}{l}\text { Tissue-specific; Heteroassociation with class I proteins; Regulation of } \\
\text { myogenesis (myogenic regulatory factors), islet cells differentiation } \\
\text { (NeuroD/Beta2), neurogenesis (Mash-1), cardiac morphogenesis (d/ } \\
\text { e-HAND), and mesoderm development (Twist) }\end{array}$ \\
\hline III & bHLH-LZ & MiT family (MiTF, TFE3, TFEB, TFEC) $[9,10]$; Myc [8] & $\begin{array}{l}\text { Melanocytes maturation (MiTF), B cells activation (TFE3), placental } \\
\text { vascularization (TFEB), osteoclast development (MiTF, TFE3, TFEC), } \\
\text { cell proliferation/differentiation, oncogenesis and apoptosis (Myc) }\end{array}$ \\
\hline IV & bHLH-LZ & Mad family (Mad1/3/4, Mxi1) [339-341], Max [7, 342] & $\begin{array}{l}\text { Homodimerization or heterodimerization with Myc; Regulation of } \\
\text { cell proliferation }\end{array}$ \\
\hline V & $\mathrm{HLH}$ & Id proteins (Id1-4) $[16,17,24,343]$ & $\begin{array}{l}\text { Heterodimerization with class I and, to a minor extent, class II } \\
\text { proteins; Regulation of cell proliferation/differentiation during } \\
\text { development and in cancer }\end{array}$ \\
\hline $\mathrm{Vl}$ & $\mathrm{b}($ Pro)HLH & HES family (HES1-7) [13] & Regulation of cell proliferation/differentiation during embryogenesis \\
\hline VII & bHLH-PAS & AhR, HIFa, SIM, ARNT [12] & $\begin{array}{l}\text { Regulation of xenobiotic (AhR/ARNT) and hypoxic (HIFa/ARNT) } \\
\text { response genes, and of neural development (SIM/ARNT) }\end{array}$ \\
\hline
\end{tabular}

(Fig. 1). Formation of the ternary complex DNA[bHLH(-LZ) $]_{2}$ triggers transcriptional activation. This, however, does not occur for class $\mathrm{V}$ proteins, as they lack the DNA-binding motif: as a result, these proteins may sequester class I and II bHLH proteins in non-DNA-binding dimers, thus acting as negative regulators of bHLH-mediated gene expression [15, 23].

This review will focus on the class V Id proteins, with the aim to give an overview of them, discussing the following aspects: (i) structural features, (ii) mode of action, (iii) biological function in physiological as well as pathological scenarios, and (iv) potential role in tumor therapy.

\section{Structural features}

The Id1 protein was first identified in 1990 by Benezra et al. [15]. Since then four mammalian Id proteins, Id1-4 [24-26], as well as Drosophila [27] and Xenopus [28] homolog proteins have been identified. In humans the four Id genes are located on chromosomes 20q11 (Id1) [29, 30], 2p25 (Id2) [29], 1p36.1 (Id3) [31, 32], and 6p21p22 (Id4) [33]. For mouse, rat and human Id1 [30, 34-38] as well as for rat and human Id3 [39, 40] a spliced form has been also detected, which differs from the canonical one only in the C-terminal domain (Fig. 2b): for example, the canonical and spliced forms of human Id1 are 155- and 149-residue long and differ from position 143 [30, 36, 38]. The canonical and spliced forms of human $\operatorname{Id} 3$ are
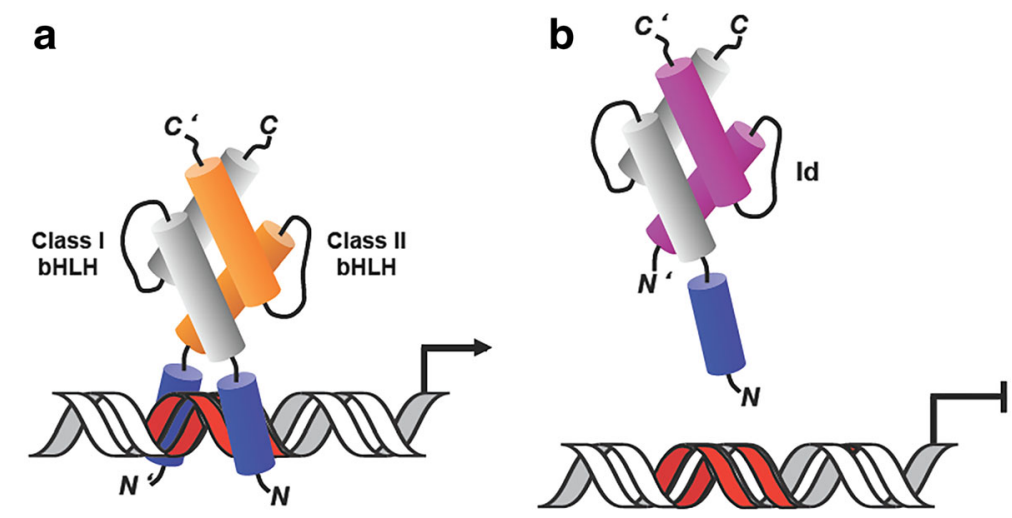

Fig. 1 Control of DNA transcription by positive and negative HLH regulators. a Broadly expressed bHLH E proteins build heterodimers with tissue-specific bHLH proteins, which results in DNA binding at specific DNA sequences (in red) and DNA-transcription activation. $\mathbf{b}$ Eprotein association with the Id proteins results in dimers with no ability to bind the DNA because the Id-protein subunit lacks the DNA binding region, which leads to inhibition of DNA-transcription activation. The helices of the HLH domains are represented by cylinders (grey for class I bHLH, orange for class II bHLH and magenta for Id); a blue-colored cylinder represents the basic DNA-binding region of the bHLH domain 


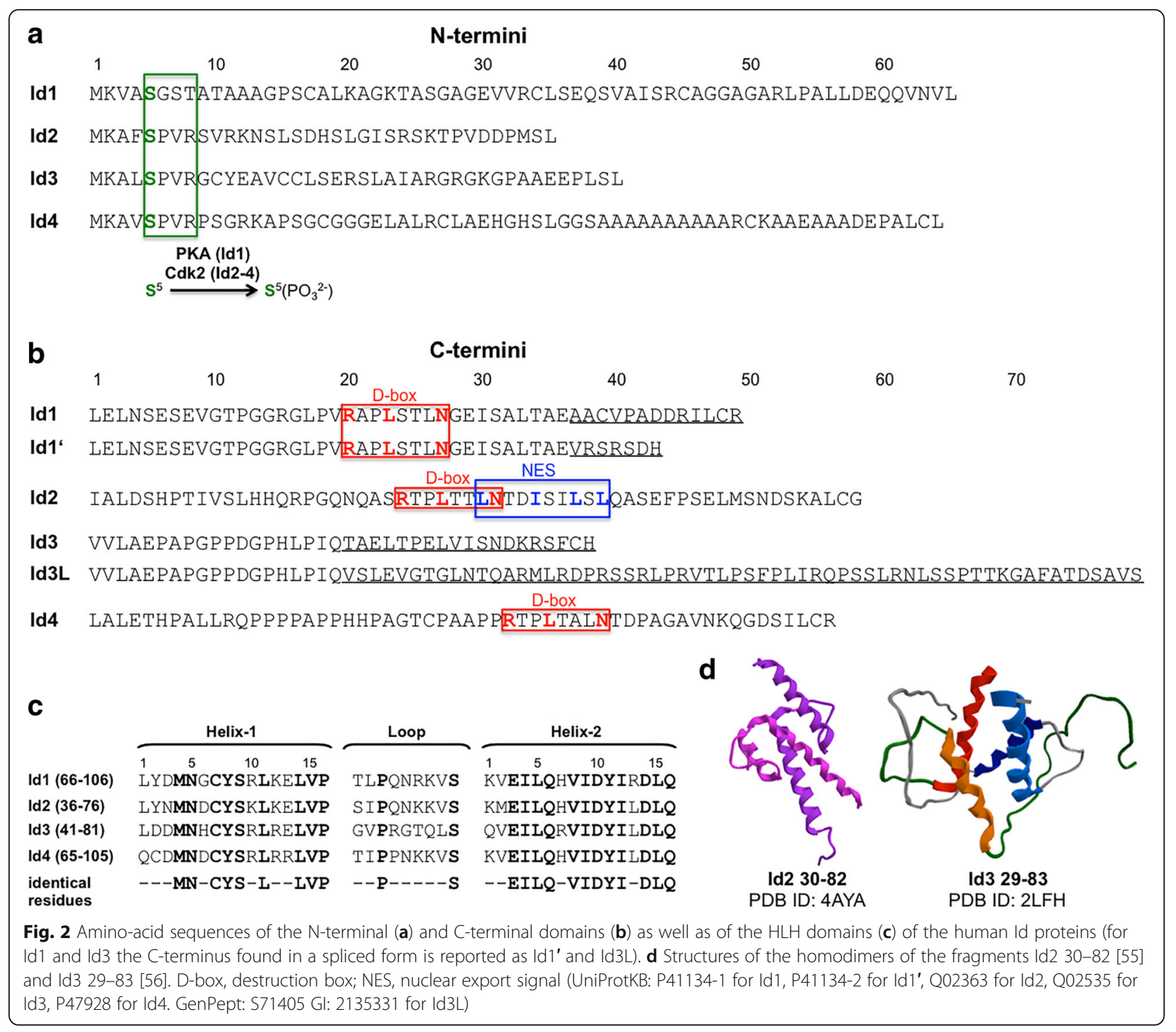

119- and 160-residue long and differ from position 101 [39]. Interestingly, the spliced form of Id1 has much higher propensity to homodimerize than the canonical form [37]. Instead, the spliced form of Id3 seems to have less affinity for the bHLH E protein E47 than the canonical form [39].

Sequence alignment of the four Id proteins reveals that the HLH domain is highly conserved, especially within the two helical motifs (helix-1 and helix-2) and at their junctions with the loop (Fig. 2c). Accordingly, the Id HLH region badly tolerates sequence modifications, resulting in altered conformation [41-44] and function [45]. Contrarily to the highly conserved HLH domain, the $\mathrm{N}$-terminal and $\mathrm{C}$-terminal domains are unique for each of the Id proteins, being different both in length and amino-acid sequence (Fig. 2a, b). Nevertheless, some common features can be found also in these regions: for example, Id $1-4$ possess a phosphorylation site at Ser-5 [46-49], and Id1,2,4 display a C-terminal destruction box (D-box) that triggers protein degradation via the anaphase-promoting complex/cyclosome $\mathrm{Apc} / \mathrm{C}$ and its activator Cdh1 (Apc/C $\left.\mathrm{C}^{\mathrm{Cdh} 1}\right)$ [50]. Instead, only Id2 contains a nuclear export signal (NES) that is recognized by the nuclear export receptor CRMP1 [51].

The HLH and flanking regions display different structural properties: indeed, the Id HLH domain undergoes self- (Id2 [52], Id3 [53, 54]) or heteroassociation with the HLH domains of class I and II proteins and folds into a four-helix bundle, as shown by the crystal structure of the Id2 HLH domain (PDB ID: 4AYA) [55] and by the solution NMR structure of the Id3 HLH domain (PDB ID: 2LFH) [56] (Fig. 2d). In contrast, the N-terminal and Cterminal domains are mainly disordered, as suggested by disorder probability prediction analysis [57-59] as well as 
by conformational data on synthetic peptides reproducing the $\mathrm{N}$-terminal and $\mathrm{C}$-terminal regions of the Id proteins $[42,43]$. Therefore, the Id proteins contain intrinsically disordered regions that, in the case of the HLH region, undergo folding upon self- or heteroassociation $[41,44,53,55,56]$. A common feature of intrinsically disordered proteins is the high propensity to aggregate and precipitate, which represents the major obstacle for the structural investigation of these proteins. Indeed, attempts to grow crystals of the full-length Id2 protein failed thus far [60], and only N-terminal and C-terminally truncated Id2 (residues 30-82) was successfully crystallized [55].

Despite the lack of a well-defined structure, the Nterminal and C-terminal domains are certainly important for the biology of the Id proteins, as supported by the presence of regulatory signals there, including ubiquitination, phosphorylation and molecular recognition elements like NES and D-box, which will be discussed in the following. In addition to the primary structure and its posttranslational modifications, it is highly probable that also the conformational dynamics of the flexible regions will play a role in protein-protein interaction events.

\section{Mode of action}

The Id proteins perform their biological function via protein-protein interactions that involve not only class I and II bHLH proteins [61-63], but also proteins belonging to other families and containing other types of domains. These include the retinoblastoma protein tumor suppressor $(\mathrm{pRb})$ and related pocket proteins $[64,65]$, the actin-associated protein enigma homolog (ENH) [66, 67], the p200 family member p204 [68, 69], Ets-domain proteins [70], MIDA1 [71, 72], Pax transcription factors [73], adenovirus E1A proteins [74], ADD1/SREBP-1c [75], the C8 subunit of the $20 \mathrm{~S}$ proteasome [76], the hepatitis B virus-encoded protein $\mathrm{X}$ (HBX) [76], the S5a subunit of the $26 \mathrm{~S}$ proteasome [77], the COP9 signalosome (CSN) subunits CSN5 and CSN7 [78], the deubiquitinase USP1 [79], the Apc/C subunits Apc1, Apc5, Apc8/Cdc23 [50], the cell-membrane protein caveolin-1 [80], the four-anda-half LIM-only protein 2 (FHL2) [81], the Von-Hippel Lindau(VHL)-elongin-C complex [82], and the estrogen receptor beta-1 (ER $\beta 1$ ) [83] (Table 2). The fact that some of these interactions are specific for individual Id-family members suggests that they are not only mediated by the highly conserved HLH motif, but also by the less conserved $\mathrm{N}$-terminal and $\mathrm{C}$-terminal regions. For example, the interaction of Id2 with the VHL-elongin-C complex is suggested to occur in a short region of the Id2 $\mathrm{N}$-terminal domain, which contains Thr-27: however, Dyrk1-mediated phosphorylation of Thr-27 prevents the interaction with the protein complex [82].

Interestingly, the presence of the unique polyalanine segment within the $\mathrm{N}$-terminus of Id4 seems to positively affect the HLH-mediated interaction of the Id4 protein with the other Id proteins [63], an observation that further underlines the structural and functional importance of the $\mathrm{N}$-terminal and C-terminal domains of the Id proteins.

\section{Regulation}

For the correct function of a protein in the cell, its expression, localization, and degradation must be strictly timely regulated. The following subsections report on the known mechanisms that regulate the Id-protein activity.

\section{Gene expression}

Usually, Id gene expression is positively regulated in undifferentiated, highly proliferative, embryonic or cancer cells [16, 84-91] (Fig. 3). For example, during development the Id gene expression is activated in stem and progenitor cells to support proliferation and inhibit differentiation, whereas it is repressed upon lineage commitment and differentiation [1,92]. Recently, it has been shown that the Id1-3 genes are targets of the nuclear factor Y (NFY) complex (NFYa-c) that binds the CCAAT box on their promoters (in contrast, the Id4 gene lacks the CCAAT box) [93]: accordingly, NFY incorporation into the Id1-3 gene promoters decreases upon induction of differentiation with retinoic acid of the human embryonic carcinoma cell line NTera2, which is a valuable cell model to study the expression profile during development. This is due to the loss of NFYc at the protein level in the differentiating cells, which results in Id1-3 genes down-regulation. Interestingly, also the epigenetic markers for gene transcription (histone 3 Lys-9 acetyl, H3K9ac) and repression (histone 3 Lys-9 dimethyl, H3K9me2) incorporated into the Id1-3 gene promoters respectively decrease and increase during differentiation. However, after 7 days of differentiation the positive regulators NFYc and $\mathrm{H} 3 \mathrm{~K} 9 \mathrm{ac}$ recover with consequent increase in Id1-3 gene expression that is required for cellular growth [93].

In primary immature thymocytes the $I d 3$ gene expression is activated by the Egr1 transcription factor that is a downstream target of the TCR-mediated activation of the RAS-ERK-MAPK pathway, which promotes thymocyte maturation upon inhibition of the $\mathrm{E}$ proteins $[84,94]$.

In vitro, treatment of cells with serum or plateletderived growth factor (PDGF) induces Id gene expression [95] (serum-induced expression of $I d 1$ is linked to the serum-dependent protein complex including the Egr1 protein [96]). Also the sex hormone estradiol positively affects $I d 1$ gene expression in human breast cancer cells, which, however, may be counteracted by progesterone [97]. $I d 1$ and $I d 3$ gene expression can be stimulated 
Table 2 Protein-protein interactions involving Id proteins

\begin{tabular}{|c|c|c|c|}
\hline Id protein & Protein partner & Description & References \\
\hline Id1-4 & Class I and II bHLH proteins & Dominant negative regulation of bHLH factors & {$[61-63,236]$} \\
\hline Id2 & pRb and related pocket proteins p107 and p130 & $\begin{array}{l}\text { Inhibition of pRb-mediated cell-cycle arrest } \\
\text { (as no interaction between the pRb small pocket } \\
\text { and Id2 was detected by mass spectrometry } \\
\text { and NMR spectroscopy [136], a multiprotein } \\
\text { complex is likely to be formed) }\end{array}$ & {$[64,65]$} \\
\hline Id 2 & $\mathrm{ENH}$ & $\begin{array}{l}\text { Id-protein localization in the cytoplasm by } \\
\text { association of the Id2 HLH and ENH LIM domains }\end{array}$ & {$[66,67]$} \\
\hline ld $1-3$ & p204 & Id-protein localization in the cytoplasm & {$[68,69]$} \\
\hline Id1-3 & Ets-domain proteins Elk-1 and SAP-1/-2 & $\begin{array}{l}\text { Inhibition of the winged-helix-turn-helix } \\
\text { transcription factors regulating the expression } \\
\text { of immediate-early response genes such as } \\
\text { c-Fos and Egr1 }\end{array}$ & [70] \\
\hline ld 1 & MIDA1 & $\begin{array}{l}\text { Inhibition of MIDA1-Z-DNA interaction with } \\
\text { stimulation of cell growth and inhibition } \\
\text { of neural differentiation }\end{array}$ & {$[71,72,344,345]$} \\
\hline Id1-3 & Pax-2/-5/-8 & $\begin{array}{l}\text { Inhibition of the paired-box transcription } \\
\text { factors involved in development }\end{array}$ & [73] \\
\hline $\mathrm{Id} 1, \mathrm{Id} 2$ & Adenovirus E1A protein & Induction of apoptosis in cells expressing p53 mutants & [74] \\
\hline $\mathrm{Id} 2, \mathrm{Id} 3$ & ADD1/SREBP-1C & $\begin{array}{l}\text { Inhibition of the bHLH-LZ transcription factor } \\
\text { that regulates the expression of adipocyte genes }\end{array}$ & [75] \\
\hline Id1 & $\mathrm{C} 8, \mathrm{HBX}$ & Induction of proteasome-mediated HBX degradation & [76] \\
\hline Id1 & S5a & Suppression of the Id-protein activity & [77] \\
\hline Id1, Id3 & CSN5 (Id1, Id3), CSN7 (Id3) & $\begin{array}{l}\text { Suppression of Id-protein ubiquitination } \\
\text { by CSN-mediated phosphorylation }\end{array}$ & [78] \\
\hline Id $1-3$ & USP1 & Id-protein deubiquitination & [79] \\
\hline Id 2 & Apc/C subunits Apc1, Apc5, Apc8/Cdc23 & Id2-protein degradation & [50] \\
\hline Id 1 & Caveolin-1 & $\begin{array}{l}\text { Induction of cell migration and chemotherapy } \\
\text { resistance in prostate cancer }\end{array}$ & [80] \\
\hline Id1-4 & FHL2 & $\begin{array}{l}\text { Antagonism of the inhibitory effect of the Id } \\
\text { proteins on E47-mediated transcription }\end{array}$ & [81] \\
\hline Id 2 & VHL-elongin-C & Inhibition of ubiquitination and degradation of HIF2a & [82] \\
\hline Id 1 & ERß1 & Inhibition of cell proliferation and p21 up-regulation & [83] \\
\hline
\end{tabular}

\section{Normal development}

\section{Serum, PDGF $[95,96]$}

Retinoic acid (epithelial cells) [98]

TGF $\beta$ (B-lymphocyte progenitors and mature B-cells) $[100,101]$

Egr1 (immature thymocytes) [84,94]

Egr2 (osteoclasts precursors) [184]

BMP2 (myoblasts, osteoblast-like cells) [102-104]

NFY (embryonic cells) [93]

Activin A (epithelial cells) [99]

TGF $\beta /$ Smad3/ATF3 (epithelial cells) [108]

TNF $\alpha /$ p38/ATF3 (epithelial cells) [108]

p53 (neural progenitor cells) [112]

\section{Cancer}

TGF $\beta$ (glioblasotma multiforme) [109]

PI3K/Akt (glioblastoma) [110]

Myc (neuroblastoma, breast cancer) $[115,116]$

BMPs (multiple myeloma, breast and lung cancer) [105-107,113]

Estradiol (breast cancer) [97]

p53 mutants (breast cancer) [111]

$\beta$-catenin/TCF (colon adenocarcinoma) [114]

Stat3 (colorectal cancer) [120]

Nicotine (non-small cell lung cancer) [117]

EGF (non-small cell lung cancer) [117]

Bcl-3 (prostate cancer) [118]

FLT3-ITD (acute myeloid lymphoma) [119]

BCR-ABL (acute myeloid lymphoma) [119]

Progesterone (breast cancer) [97]

Fig. 3 Selected molecules/pathways involved in the regulation of Id gene expression in normal development and cancer 
by retinoic acid in keratinocytes [98]. In contrast, the cytokines activin-A and TGF $\beta 1$ lead to suppression of Id1, $I d 2$ and $I d 3$ gene expression in keratinocytes [99]. However, TGF $\beta 1$ has been shown to induce Id 3 gene expression in B-lymphocyte progenitors, resulting in inhibition of their growth and survival [100], as well as Id2 gene expression in mature B cells, preventing IgE class switching [101]. Bone morphogenic protein 2 (BMP2), another cytokine from the TGF $\beta$ family, positively affects $I d 1$ gene expression in myoblasts [102, 103], osteoblast-like cells [104], breast [105] and lung $[106,107]$ cancer cells. In epithelial cell lines, the BMP2-mediated Id1 gene expression may be counteracted by the TGF $\beta / \mathrm{Smad} 3$ or $\mathrm{TNF} \alpha / \mathrm{p} 38$ pathways that activate the stress response factor and transcriptional repressor ATF3 [108]. Instead, TGF $\beta$ does not induce ATF3 in glioblastoma multiforme, which turns the TGF $\beta$-mediated transcription of $I d 1$ from repression to activation [109]. In glioblastoma cells Id1 expression is also PI3K-dependent through the phosphorylation of 4E-BP1 via Akt-mTORC1 or AktPPM1G. Increase in the phosphorylation state of $4 \mathrm{E}-$ BP1 results in the activation of Id1 translation, leading to increased Id1 expression and glioblastoma malignancy [110].

Mutations of p53 have been shown to positively regulate the transcription of the Id4 gene in breast cancers: indeed, complexes of p53 mutants and E2F1 bind to the Id4 promoter and activate Id4 expression [111]. Instead, $I d 2$ expression is down-regulated by the transcriprional repressor p53 in neural progenitor cells [112].
In multiple myeloma the $I d 1$ and $I d 2$ gene expression is induced by over-expressed BMPs, which supports cell proliferation [113]. In colon adenocarcinoma the $I d 2$ gene is a target of the $\beta$-catenin/T-cell factor transcription pathway and induces the clonogenic growth of the colon cells [114]. In neuroblastoma the Id2 gene is activated by Myc oncoproteins, which leads to the inhibition of the $\mathrm{pRb}$ tumor suppressor pathway with consequent cell-cycle progression [115]. In breast cancer Myc upregulates Id3 that supports the entry in the S-phase by enhancing the cyclin/Cdk activity [116]. In non-small cell lung cancer the activation of the $I d 1$ gene promoter can be induced by nicotine and EGF in a Src-dependent manner, which leads to the down-regulation of ZBP-89, a zinc finger transcriptional repressor of the mesenchymal markers fibronectin and vimentin [117]. In prostate cancer the over-expression of B-cell leukemia 3 (Bcl3) protein is correlated with the expression of Id1 and Id2, which is in turn accompanied with resistance to proapoptotic drugs [118]. In acute myeloid leukemia Id1 has been shown to be a target of the oncogenic tyrosine kinases FLT3-ITD and BCR-ABL, which results in protection of the cells against TRAIL-induced apoptosis [119]. In colorectal cancer Stat3 mediates the transcriptional activation of the IdI gene, which correlates with p53 inactivation [120].

\section{Phosphorylation}

Id 2 and Id 3 may be phosphorylated at Ser- 5 by Cdk2 at the $G_{1}-S$ transition [46-48, 121-123] (Fig. 4). Phosphorylated Id 2 accumulates in the nucleus and seems to be
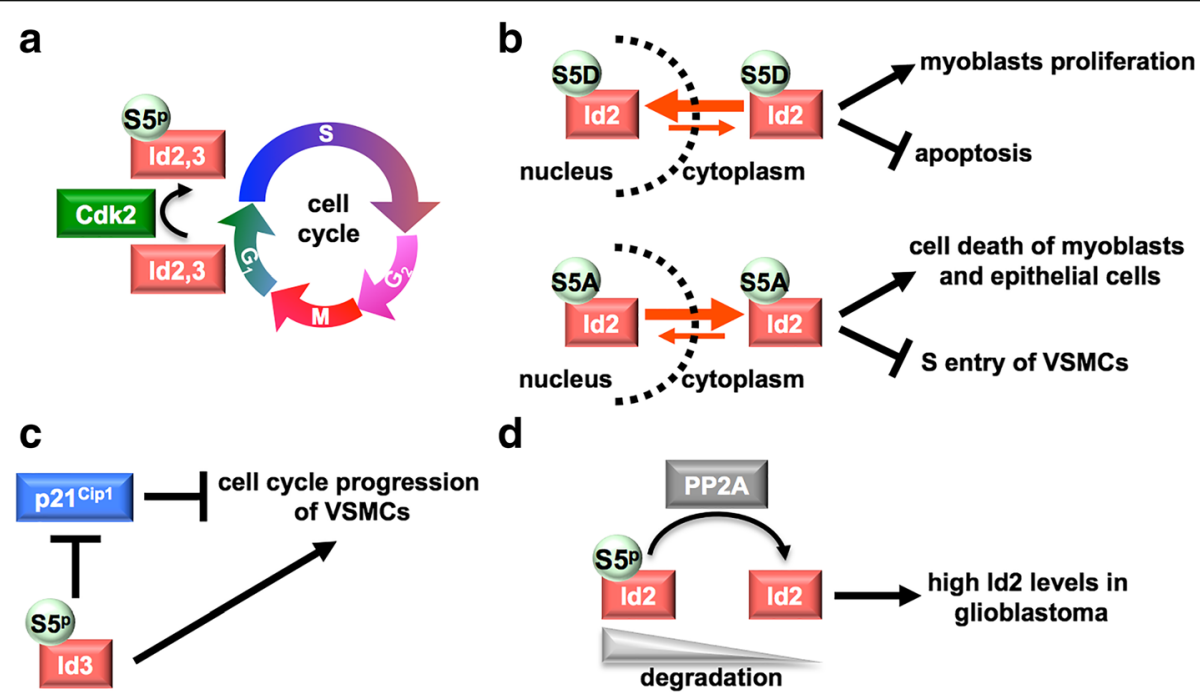

Fig. 4 Phosphorylation of Id 2 and Id3. These proteins are phosphorylated by Cdk2 at the $\mathrm{G}_{1}-\mathrm{S}$ transition $[46-48,121-123]$ (a). Phosphorylated Id2 (or its S5D mimic) accumulates in the nucleus, whereas phosphoablated Id2 (S5A) accumulates in the cytoplasm and induces cell-cycle arrest or apoptosis $[121,122]$ (b). Phosphorylated Id3 induces cell-cycle progression of VSMCs via inhibiting the cell-cycle blocker p21 ${ }^{\text {Cip } 1}$ at the transcriptional level [123] (c). Phosphorylated Id2 is less resistant to degradation than unphosphorylated Id2. In glioblastoma high Id2 levels can be maintained by PP2A activity (d) [124] 
key player in cell-cycle regulation, as the phosphoablated mutant (Ser-5-Ala-Id2) induces apoptosis of myoblasts [121] and mammary epithelial cells [122], as well as it inhibits the entry in the S-phase of vascular smoothmuscle cells (VSMCs) [123]. Also Id3 phosphorylation is important for VSMCs proliferation: it has been proposed that phosphorylation of Id 3 at the $\mathrm{G}_{1}-\mathrm{S}$ transition contributes to suppress the Cdk2- and cell-cycle-blocker p $21^{\text {Cip1 }}$ in the early $G_{1}$ phase, further supporting the linkage between Id3 phosphorylation and cell-cycle progression [47]. The negative effect of Id3 phosphorylation on the p $21^{\text {Cip } 1}$ levels is probably due to enhanced ability of the phosphoprotein to inhibit transcriptional activation of $p 21^{C i p 1}$ in comparison to the phosphoablated (Ser-5-Ala-Id3) and non-phosphorylated protein, an assumption that may be justified by the observation that Ser-5 phosphorylation seems to affect the proteinprotein interaction properties of Id3 (as well as of Id2), at least with respect to the class I bHLH proteins [46-48].

In neural precursor cells the $\mathrm{N}$-terminal Id2 phosphorylation regulates the expression level of the protein: indeed, a phosphoablated mutant appears to be protected against proteasome-dependent degradation, thus promoting proliferation. Moreover, the phosphatase PP2A has been shown to maintain high Id2 levels in glioblastoma: in contrast, inhibition of selected PP2A subunits in glioblastoma-derived stem cells (GSCs) decreases Id2 levels as the result of regained protein phosphorylation and enhanced degradation [124].

Unlike Id2 and Id3, Id1 has been found to be phosphorylated at Ser-5 by PKA, which apparently blocks the nuclear export of the protein [49].

\section{Degradation}

The Id proteins are short-living proteins with halflives shorter than one hour $[125,126]$. The proteins Id1-3 are degraded via the $26 \mathrm{~S}$ proteasome pathway upon N-terminal ubiquitination, whereas Id4 degradation is dependent from the E1 enzyme [125]. Proteasome-mediated degradation of $\mathrm{Id} 1$ and $\mathrm{Id} 3$ is negatively regulated by the COP9 signalosome (CSN) that directly interacts with the proteins and induces their phosphorylation [78]. Moreover, the deubiquitinase USP1 can associate with and deubiquitinate Id13 in mesenchymal stem cells, thus preserving their stem cell state [79]. Also the interaction of the Id proteins with their bHLH binding partners protects them from fast degradation [125-127]. In contrast, degradation of Id1, Id 2 and Id4 is triggered by Apc/ $\mathrm{C}^{\text {Cdh1 }}$ that recognizes the destruction box (D-box) motif, RXXLXXXN, located C-terminally of the HLH domain (Table 3) [50].
Table 3 D-box and NLS/NES motifs of the Id proteins

\begin{tabular}{ll}
\hline Id motif & Amino-acid sequence \\
\hline D-box & \\
Id1 (126-133) & RAPLSTLN \\
Id2 (100-107) & RTPLTTLN \\
Id4 (137-144) & RTPLTALN \\
NES-like & \\
Id1 (98-109) & VIDYIRDLQLEL \\
Id2 (106-115) & LNTDISILSL \\
NLS-like & \\
Id1 (74-91) & SRLKELVPTLPQNRKVSK \\
Id2 (44-61) & SKLKELVPSIPQNKKVSK
\end{tabular}

The D-box motifs are recognized by $\mathrm{Apc} / \mathrm{C}^{\mathrm{Cdh} 1}$ and trigger Id-protein degradation. The characteristic D-box amino-acid positions are in bold [50]. The NLS/ NES motifs regulate the Id-protein nucleo-cytoplasmic shuttling [51, 126, 129]. The hydrophobic residues important for the nuclear export are in bold. The conserved basic positions in the NLS motifs are in bold

\section{Subcellular localization}

The Id proteins may be found both in the nucleus and in the cytoplasm [128], and their nucleo-cytoplasmic distribution is regulated either by passive diffusion, due to their small size (13-18 $\mathrm{kDa})$, or by nuclear localization/ export signals (NLS/NES) embedded in their sequences, which regulate the nucleo-cytoplasmic shuttling by binding nuclear pore complexes (Table 3). Id1 [129] and Id2 [51] contain a NES motif in the HLH domain and in the C-terminus, respectively. Although the Id proteins lack canonical NLS motifs, it is likely that the basic residues present in the HLH domain fulfill the task of nuclear localization, as it has been shown for Id1 [126]. However, in the case of Id3, which lacks the basic-residue pattern shown by Id 1 and Id2, the HLH domain seems to be enough for nuclear localization: indeed, Id3 has been shown to accumulate in the nucleus or in the cytoplasm upon co-expression with or in the absence of bHLH E47, respectively [127]. This suggests that the bHLH protein, which contains its own NLS, my act as a carrier of the Id protein into the nucleus. The localization of Id2 in the cytoplasm may be positively regulated by the cytoplasmic protein ENH that is able to interact with the Id2 protein and to retain it in the cytoplasm: the Id2 HLH domain and at least one of the three LIM domains of ENH mediate the interaction between the two proteins [66].

\section{Cell-cycle regulation}

The Id proteins contribute to the regulation of the cell cycle in the $G_{1}$ phase, mainly by antagonizing the transcriptional activation of differentiation-associated genes like the Cdk inhibitors $p 15, p 16$ and $p 21$ mediated by the class I bHLH proteins [130] and Ets-domain proteins 
[131], promoting cell-cycle progression [132-134] or inhibiting cell senescence [135] (Fig. 5).

Besides Cdk inhibitors, the Id proteins affect also other cell-cycle regulators, including $\mathrm{pRb}$ and $\mathrm{p} 53$. Id2, but not the other Id proteins, has been shown to interact with the hypophosphorylated, active form of $\mathrm{pRb}$ and with the pRb-related pocket proteins p107 and p130, which abrogates their cell-cyle arrest activity [64, 65]. The mode of interaction between $\mathrm{pRb}$ and $\mathrm{Id} 2$ is not fully understood and, probably, it includes a multidomain interaction, since the small pocket domain of $\mathrm{pRb}$ is not able to bind Id2 in vitro [136]. Unlike Id2 that affects the $\mathrm{pRb}$ pathway by physically interacting with the members of the $\mathrm{pRb}$ family, Id1 and Id 3 are likely to indirectly regulate the $\mathrm{pRb}$ activity by binding to Etsdomain proteins [70] or class I bHLH proteins [130] and thus decreasing the expression of p16 [131, 135, 137] or p21 [138], potent inhibitors of the cyclin/Cdk complexes that mediate $\mathrm{pRb}$ phosphorylation. Hyperphosphorylated $\mathrm{pRb}$ is no longer able to bind the transcription factors E2F1-3 that, thus, activate cell division and may trigger tumorigenesis [139].

Id1 is able to impair the p53-mediated response to DNA damage, which has been attributed to the negative

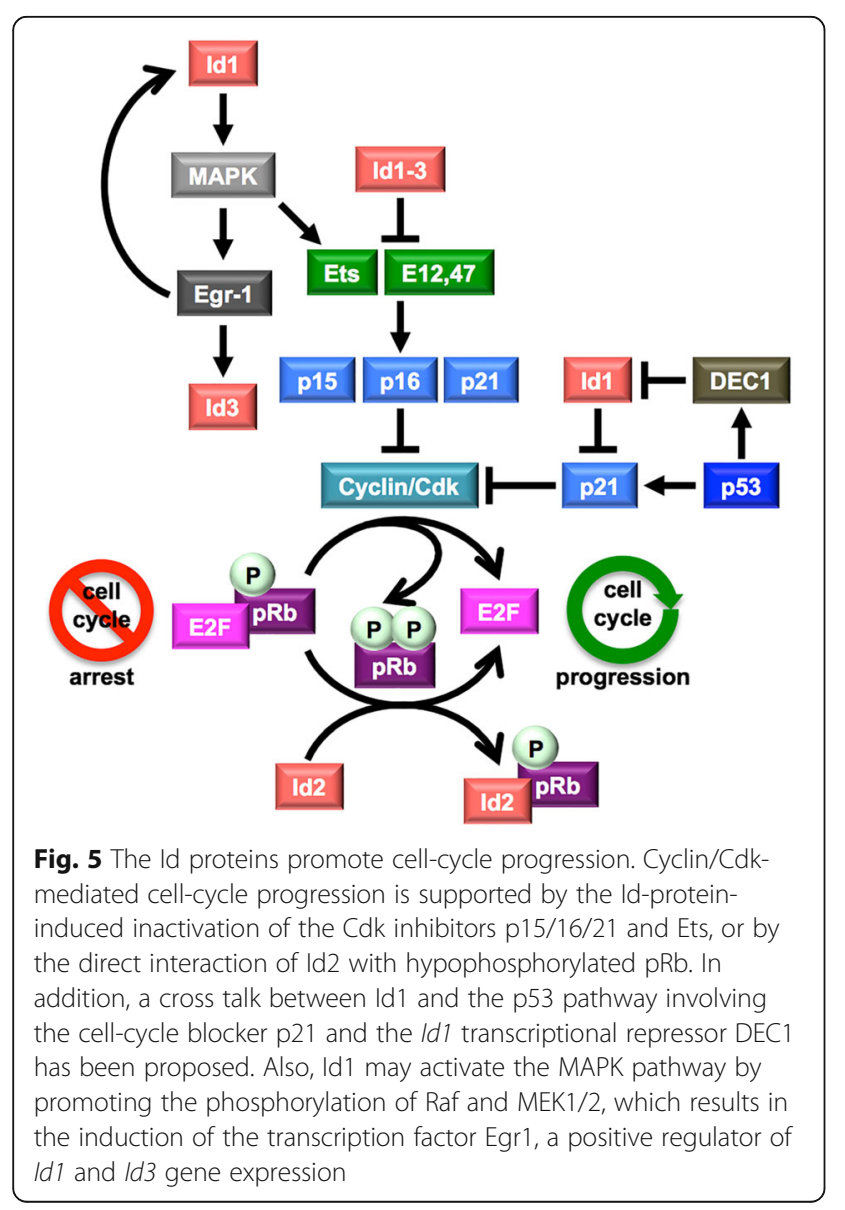

effect of Id1 on p21 expression; in contrary, p53 upregulates the bHLH transcription factor DEC1 that, in turn, down-regulates Id1 [138]. This indicates a cross talk between p53 and Id1, which regulates cell-cycle arrest and senescence versus cell-cycle progression.

Id-protein induced cell proliferation has been also correlated to activation of the MAPK (mitogen-activated protein kinase) signaling pathway [140]. Indeed, Id1 promotes not only phosphorylation of Raf and MEK1/2, which are key regulators of the MAPK pathway, but also Egr1 expression, which is a downstream effector of the activated MAPK pathway and, in turn, activates the transcription of the Id1 gene [96]. This suggests that Id1 is not only a positive upstream regulator but also a downstream target of the MAPK signaling pathway [96, 140]. Also the Id3 gene is a downstream target of Egr1 upon TCR activation of the ERK MAPK pathway [94].

\section{Id proteins in developmental processes and disorders}

The Id proteins play a key role during development $[16,86,91,141]$. Based on Id gene knockout animal models, single knockout leads to developmental defects of different entity, depending on the lacking $I d$ gene [142-148] (Table 4). Instead, the double knockout of IdI and Id3 leads to embryonic lethality [149]. This suggests that Id3 can compensate loss of Id1 during embryonic development.

\section{Neural processes}

Id1 and Id3 are highly expressed in the early stages of the central nervous system, whereas their levels decrease in the late stages [150-152], which suggests a role of these proteins in stimulating neural precursor cells proliferation while inhibiting differentiation. In the case of Id 2 and Id4, their expression is retained also in adulthood [88, 153, 154].

During neural development Id2, E47 and pRb contribute to the regulation of the cell cycle mainly by controlling

Table 4 Id gene knockout studies in mice

\begin{tabular}{ll}
\hline Deleted gene & Phenotype \\
\hline $\mid d 1-/-$ & Decreased neovascularization [146] \\
$\mid d 2-/-$ & $\begin{array}{l}\text { Lack of Langerhans and splenic dendritic } \\
\text { cells, reduced number of NK cells, altered } \\
\text { peripheral lymphoid organs [143, 147] }\end{array}$ \\
& $\begin{array}{l}\text { Defects in B-cell activation and proliferation } \\
\text { upon B-cell receptor signaling, and in both } \\
\text { negative and positive selection of T-lineage } \\
\text { progenitors [144, 145] }\end{array}$ \\
$|d|-$ & $\begin{array}{l}\text { Altered brain size, defects in forebrain } \\
\text { development [142, 148] }\end{array}$ \\
$|d 1-/-| d 3-,/-$ & $\begin{array}{l}\text { Embryonic lethality with cranial hemorrhage, } \\
\text { small brain size, premature neural differentiation [149] }\end{array}$ \\
&
\end{tabular}


the Cdk inhibitor p57 ${ }^{\mathrm{Kip} 2}$, which is essential for cell-cycle arrest and differentiation. The transcription of $p 57^{K i p 2}$ is activated by E47 and indirectly repressed by Id2, which inhibits E47. However, pRb may counteract the inhibitory activity of Id2. Therefore, it has been suggested that $\mathrm{p} 57^{\mathrm{Kip} 2}$ acts as proliferation checkpoint during brain development. However, this checkpoint may be override by up-regulated Id2 leading to hyper-proliferation and development of neuroblastoma [155].

Also p53 plays an important role in maintaining normal neural progenitor cells (NPCs) proliferation, and it acts as repressor of $I d 2$ gene expression by binding a conserved site within its promoter. In contrast, mutated p53 in glioma is associated to elevated Id2 expression and thus to increased proliferation and self-renewal of glioma stem-like cells [112].

Id 2 and Id4 play a crucial role in regulating the glioblastoma multiforme (GBM) stem-like cells differentiation, thus reducing their cancer initiating potential. Indeed, upon induction of differentiation with histone deacetylase inhibitors, Id2 and Id4 are up-regulated and promote neuronal/astroglial differentiation at the expense of oligodendroglial differentiation by antagonizing the oligodendroglial lineage-associated transcription factors (Olig) 1 and 2 at the transcriptional level [156].

Because of the important role of the Id proteins in neural development [157], their deregulation may not only be implicated in tumor formation but also in neurodevelpmental disorders. For example, as Id2 and Id4 inhibit oligodendroglia differentiation [62], which is required for remyelination, they might have a role in multiple sclerosis that is characterized by axonal demyelination [158, 159]. Furthermore, the Id proteins might be involved in the Rett-syndrome (RTT): indeed, the Id gene transcriptional repressor MECP2 is mutated in RTT, which leads to overexpression of the Id proteins and altered neuronal maturation [160].

Traumatic brain injury leads to enhanced BMP2 and Id3 expression in the stem cells niche of the subventricular zone. Id3, in turn, inhibits the bHLH-mediated transcriptional repression of various astrocyte-specific genes. This leads to the differentiation of neural stem/ precursor cells into astrocytes [161].

\section{Immune system-related processes}

The class I bHLH proteins E12, E47 and HEB, and the Id proteins are major players in B-cell and T-cell development [162-166]. For example, the Id proteins are highly expressed in progenitor B-cells, whereas they decrease during differentiation to pre- $\mathrm{B}$ cells and mature B-cells, which inversely correlates with bHLH activity [165]. Additionally, Id2 enhances erythroid development by affecting the activity of the Ets-domain protein PU.1, a regulator of erythromyeloid development, and of the zinc-finger protein GATA-1: Id2 is able to interact with PU.1 and prevent the PU.1-GATA-1 interaction, thus initiating the myeloid versus erythroid program [167].

Recently, Id3 has been correlated to the TGF $\beta$ - and interleukin (IL4)-mediated signaling that controls the differentiation of $\mathrm{CD}^{+}$IL9 producing helper $\mathrm{T}\left(\mathrm{T}_{\mathrm{H}} 9\right)$ cells. Indeed, TGF $\beta 1$ and IL4 act as Id 3 transcriptional repressors, which results in E-protein- and GATA-3mediated activation of the $I L 9$ gene transcription and even in enhanced anti-tumor response of the T cells in a melanoma mouse model [168].

The Id proteins are not only crucial for the proper development of the immune system, but they are also involved in immune response and may play an important role in regulating immunoglobulin gene expression. Indeed, the Id proteins have been found to inhibit immunoglobulin class switch recombination (CSR) to IgE in activated B-cells in response to TGF $\beta 1$ [101, 163, 169], which suggests a protective role of the Id proteins to prevent harmful immune reactions like allergic hypersensitivity. Moreover, Id2 is up-regulated in $\mathrm{CD}^{+} \mathrm{T}$-cells as well as in memory $\mathrm{CD}^{+}$T-cells during infection, whereas Id2-deficient $\mathrm{CD}^{+}{ }^{+} \mathrm{T}$-cells show altered expression of genes influencing survival as well as impaired memory formation in response to infection [170]. Also, loss of Id2 in Tcells during influenza virus infection and in a model of acute graft-versus-host disease (GVHD) has been shown to increase IL10 levels [171]. This suggests that the Id proteins play a role in regulating survival of mature T-cells.

Then, TGF $\beta$ - or IL6-mediated up-regulation of Id1 in bone-marrow-derived myeloid cells has been shown to induce immunosuppression during tumor progression by inhibiting myeloid differentiation, while inducing pathologically activated immature cells, like myeloidderived suppressor cells, and regulatory T-cells [172]. This shows that Id1 plays a role in tumor-induced immunosuppression.

\section{Mammary gland development and disorders}

Mammary epithelial cells are characterized by decreased Id1-protein expression upon treatment with differentiation signals, whereas they start to proliferate upon constitutive Id1 expression [173]. Unlike Id1, Id2 has been found to be highly expressed in differentiated mammary epithelial cells [174]. Instead, Id2 deficiency leads to impaired proliferation and survival of mammary epithelial cells and to defects in alveologenesis in pregnant mice, resulting in lactation defect [175]. During mammary gland development Id4 expression suppresses p38MAPK activation, thus promoting cell proliferation and preventing apoptosis [176]. 


\section{Skin development and disorders}

The Id proteins regulate keratinocyte proliferation and differentiation. Id1, Id2, and Id3 are expressed in proliferating human primary keratinocytes, but they are down-regulated upon induction of differentiation [177]. In contrast, the Id proteins are further expressed in squamous cell carcinoma 9 (SCC9) and $\mathrm{HaCaT}$ cells also upon treatment with differentiation stimuli, as well as in SCC sections with poor up to high differentiation [177]. However, in the case of Id3 it has been reported that this protein induces apoptosis of SCC cells through Elk-1mediated caspase-3/-8 activation. A truncated variant of Id3 lacking the $\mathrm{N}$-terminus is even a stronger inducer of apoptosis, probably because of the loss of the Cdk2 Ser5 phosphorylation site, which abolishes $\mathrm{Cdk} 2$ regulation of the Id3 function [178]. This observation has led to the question, whether Id3 might play a tumor suppressor role in SCC.

Up-regulation of Id1 has been observed upon skin injury [179] and in psoriatic skin [180], which favors cell migration and proliferation. However, Id-protein expression is down-regulated during wound repair, which is induced by activin, a member of the TGF $\beta$ family involved in skin morphogenesis and wound healing [99].

\section{Bone formation}

The Id proteins are important for the regulation of osteoblast differentiation of mesenchymal stem cells and bone-matrix formation, which is mediated by BMP2/6/9. Indeed, the Id proteins promote the proliferation of early osteoblast progenitor cells upon BMP9 stimulation, however, they are down-regulated during the terminal differentiation of committed osteoblasts [181].

In the case of osteoclast differentiation the Id proteins are down-regulated by the TNF-related activationinduced cytokine TRANCE that induces osteoclast formation from monocytes/macrophages via different transcription factors, including the bHLH Mi transcription factor (MiTF): the latter may bind the promoter of the osteoclast-associated receptor OSCAR, whereas it may be inhibited upon sequestration by the Id proteins [182, 183]. RANKL-mediated osteoclastogenesis may be inhibited by Egr2, which is a positive regulator of the Id genes, whereas Egr2 knockdown decreases Id2 expression, thus enhancing osteoclastogenesis [184].

\section{Myogenesis}

In the course of myogenesis, myoblasts are differentiated into myotubes. This process is regulated by the highly coordinated interplay of the myogenic regulatory factors MyoD, Myf-5/-6, myogenin, and Mrf4 (class II bHLH proteins) and their binding partners, the class I E proteins and the class V Id proteins. The transcription of muscle-specific target genes is activated by heterodimers formed between the myogenic regulatory factors and the E proteins. Id1, Id2 and Id3 prevent skeletal muscle differentiation by sequestering the $\mathrm{E}$ proteins, thus blocking the activity of MyoD and other myogenic bHLH proteins $[15,185]$. This inhibition is overcome by p204, a p200 protein family member that binds the Id proteins and also triggers a decrease in their level, presumably by shuttling them from the nucleus to the cytoplasm and thus accelerating their degradation [68, 69]. Indeed, it has been reported that in proliferating $\mathrm{C} 2 \mathrm{C} 12$ myoblasts MyoD and Id1 are co-localized in the nucleus, while in differentiated myotubes $\mathrm{MyoD}$ is located in the nucleus and Id1 in the cytoplasm [186]. Furthermore, it has been observed, that Id2 reduces the myogenic markers MyoD and myogenin in myoblasts, however, ENH1 overexpression restores myogenic differentiation by binding Id2 [67].

\section{Angiogenesis}

The formation of new blood vessels out of preexisting ones, so called angiogenesis, is an important process during development and wound healing. First evidence of a role of the Id proteins in angiogenesis has been provided by a study on $I d 1 / I d 3$ double knockout mice embryos that died due to hemorrhage in the forebrain and absence of blood vessels in the neuroectoderm. Interestingly, already a partial reduction of the Id levels in adult mice may reduce vascularization, growth and metastasis of tumor xenografts [149].

Thrombospondin-1 (TSP-1) has been identified as a target gene for Id1-mediated transcriptional repression [146]. TSP-1 is a glycoprotein known to be a potent inhibitor of in vivo neovascularization and tumorigenesis. In contrast, Id 1 promotes these two events by inhibiting the transcription of the TSP-1 gene via a yet unknown mechanism.

Another key player in angiogenic events is the vascular endothelial growth factor (VEGF): loss of Id1 function has been shown to inhibit basic fibroblast growth factorand VEGF-induced angiogenesis [146, 149].

\section{Granulopoiesis}

Granulopoeisis is the differentiation of primitive blood precursors into granulocytes primarily within the bone marrow. It has been shown that Id1 is up-regulated during early granulopoiesis and down-regulated during final maturation. In contrast, Id2 is up-regulated in terminally differentiated granulocytes. Constitutive expression of Id1 or Id2 in CD34(+) cells leads to different responses, indicating a different role of the two proteins in granulopoiesis: Id1 inhibits eosinophil development while enhancing neutrophil differentiation, whereas Id2 promotes final maturation of both eosinophils and neutrophils [187]. 


\section{Stem cells}

Stem cells are mother cells that have the potential to differentiate into any specialized cell type in the body. They are able to self-renew or multiply; additionally, they play an important role in development and in the repair system of adult organisms. The Id proteins are expressed by embryonic and somatic stem cells, and initiate stemness by enhancing proliferation and inhibiting differentiation [188-191]. For example Id1 sustains the hematopoietic stem cell (HSC) selfrenewal by inhibition of differentiation and keeping the undifferentiated state [188]. Moreover, in vitro Id1, Id2, and Id3 have been shown to increase the self-renewal and proliferation potential of cortical neural stem cells (NSCs), while inhibiting neuronal differentiation [188, 192]. Indeed, the Id proteins are critical for the adhesion of NSCs to their niche, as they negatively regulate the bHLH-mediated activation of Rap1GAP, thus preserving the GTPase activity of Rap1, a regulator of cell adhesion. In contrast, decreased Id expression leads to stemness loss of NSCs that undergo premature differentiation along the neuronal and oligodendroglial lineages at the expense of the astrocytic lineage [193].

The Id2 protein has been also shown to up-regulate the bHLH transcription factor Hes1 that is important to prevent premature neurogenesis of NSCs [194]. In contrast, Id2 negatively regulates NSCs self-renewal in the developing mouse cortex [195]. Pax7, a regulator of skeletal muscle stem cells, inhibits the premature differentiation of quiescent satellite cells by inducing Id2 and Id3 expression [196].

The Id proteins also occur in cancer stem cells, for example in glioma stem-like cells (GSCs), where Id3 induction through the EGFR/Akt/Smad5 pathway leads to acquirement of GSCs characteristics and angiogenesis [197]. Id1 has been proposed to regulate normal and malignant mammary basal stem cells through Wnt/ $\beta$-catenin/TCF/c-Myc pathway activation. Accordingly, overexpressed Id1 may lead to oncogenic transformation of mammary stem cells, which promotes cancer stem cell activity in breast cancer cells [198].

\section{Id proteins and cancer}

In contrast to normal cells, cancer cells present dysregulated cellular pathways resulting in uncontrolled cell division and spreading to adjacent tissue (invasion) as well as to distant sites (metastasis). As the Id proteins are involved in cellular pathways regulating proliferation and differentiation, it is not surprising to find them contributing to tumor-related processes $[92,141]$.

\section{Id proteins are involved in tumorigenesis and tumor progression}

Although the Id proteins do not strictly meet the classical definition of oncogenes, as no tumor-associated mutations in the $I d$ genes have been observed, with the exception of $I d 2$ in the colorectal cancer cell line HRT-18 [82] and of Id3 in Burkitt lymphoma [199], the fact that Id-protein up-regulation not only is mediated by oncogenes like Myc, Ras, and (EWS)-Ets, but it also negatively affects tumor suppressor pathways (e. g. p53, pRb), emphasizes their importance in tumorigenic events. Elevated Id mRNA and protein levels have been found in many tumor types [86, 113-115, 117-119, 200-204], in which they have been often associated with poor prognosis.

The major role of the Id proteins in tumorigenesis is likely to be mediated by the inhibition of bHLH transcription factors and cell differentiation; however, an alternative mechanism might involve a disturbing effect of the Id proteins on the centrosomes. Centrosomes are the primary microtubule organizing centers (MTOC) in mitotic and post-mitotic cells. They are located adjacent to the nucleus and are regulators of cell-cycle progression. It has been shown that a fraction of Id1, but not of the other Id proteins, localizes to the centrosomes and mitotic spindle poles via binding to S5a, causing abnormal centrosome and centriole numbers [205-207]. These defects in the centrosome duplication presumably contribute to genomic instability and tumor formation, as they decrease the accuracy of mitotic replication. This property of the Id1 protein has been attributed to the presence of its N-terminal and HLH regions.

The role of the Id proteins in different types of cancer is briefly described in the following subsections and summarized in Fig. 6.

\section{Carcinoma}

\section{Breast cancer}

High levels of Id1 expression in several breast cancer cell lines are associated with high aggressiveness and invasiveness [116, 208-210]. Contrarily to Id1, Id2 is downregulated in aggressive and invasive breast carcinomas, while it is up-regulated in differentiated breast cancer cells $[211,212]$. Id1 expression may be induced by estrogen, which stimulates proliferation, whereas it may be down-regulated by progesterone. Accordingly, cells treated with Id1 antisense oligonucleotides proliferate slowly upon estrogen stimulation, whereas constitutive expression of Id1 abrogates the inhibition of breastcancer cell growth by progesterone, which is known to block the growth and invasiveness of progestin-receptor positive cancers. These results indicate that Id1 overexpression can be, at least in part, responsible for the development of the hormone refractory stage of breast cancers [97]. 


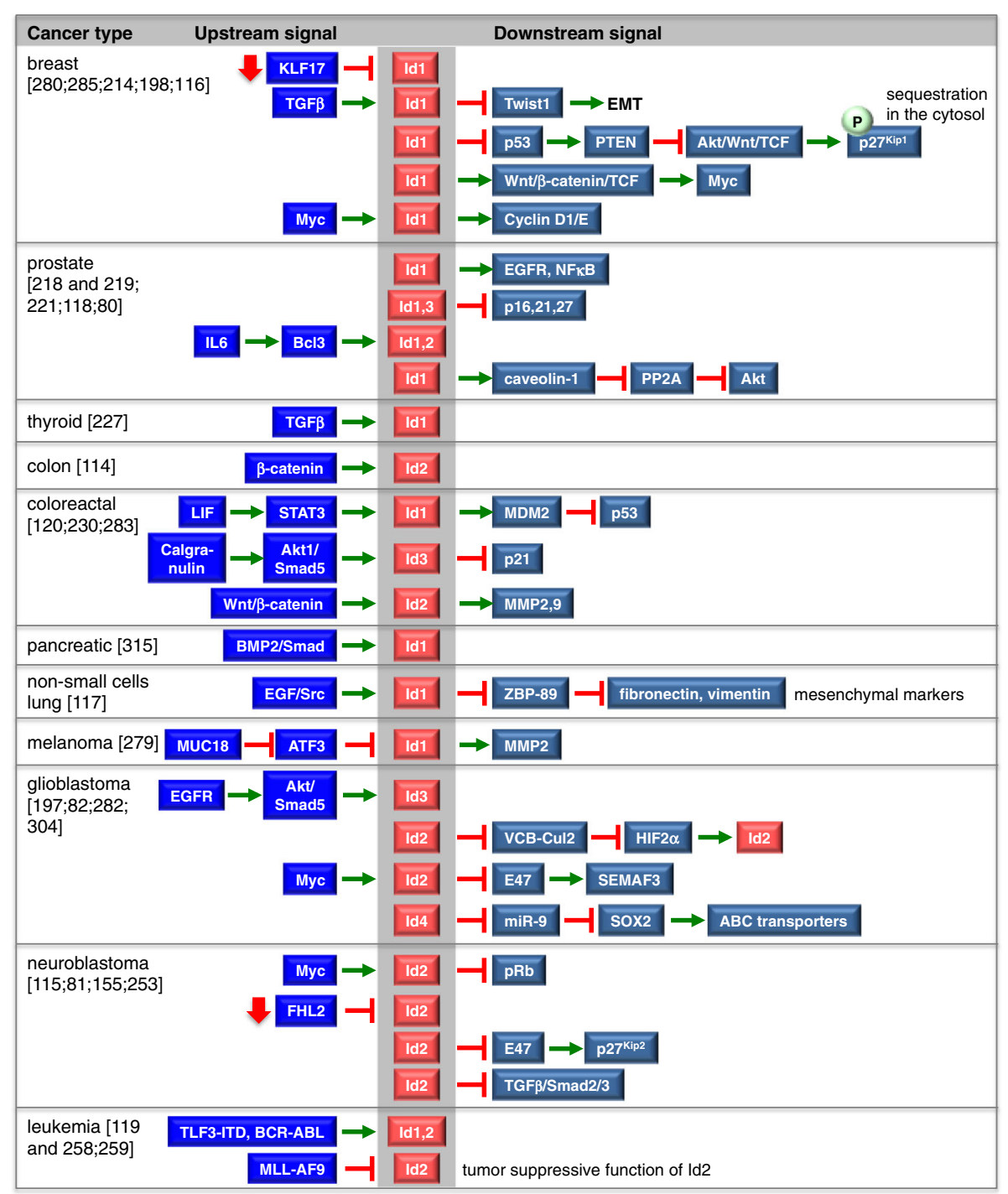

Fig. 6 Upstream and downstream signals of the Id proteins in some cancer types

Clinical studies have shown that breast cancer patients with negative estrogen receptor status are characterized by high Id1 expression, cell migration and poor prognosis [204]. In contrary, ER $\beta 1$ has been identified as a novel binding partner and inhibitor of Id1, which supports ER $\beta 1$-induced E-cadherin expression, resulting in the inhibition of the migration and invasion of breast cancer cells [213].

The tumorigenic role of Id1 in breast carcinogenesis has been associated to the inhibition of phosphatase and tensin homolog deleted on chromosome 10 (PTEN) at the transcriptional level through p53 down-regulation. Id3-mediated PTEN inhibition results in the activation of the Akt/Wnt/TCF pathway and in the cytosolic sequestration of $\mathrm{p} 27^{\text {Kip } 1}$ by its phosphorylation [214].

\section{Prostate cancer}

It has been proposed that in androgen-dependent prostate cancers androgen might regulate proliferation, apoptosis and tumor suppression via $\mathrm{Id} 1 / \mathrm{Id} 3, \mathrm{Id} 2$ and $\mathrm{Id} 4$ regulation, respectively. In contrast, lack of this regulation in androgen-independent cancers might lead to cell proliferation (Id1 and Id3 up-regulation), cell survival (Id2 down-regulation) and decreased tumor suppression (Id4 down-regulation) [215-217]. Additionally, overexpression of Id1 activates EGFR and NF- $\mathrm{B}$, resulting in aggressive tumor progression [218, 219]. Interestingly, it has been suggested that low levels of PSA and PSAP in aggressive prostate cancer might be due to Id1 overexpression [220]. Furthermore, up-regulated Id1 and Id3 expression decreases all three cell-cycle inhibitors p16, p21, and p27, leading to increased cell proliferation [221]. 
While Id4 is highly expressed in normal prostate epithelial cells, it decreases in prostate cancer cells in a stage-dependent manner and correlating with Id4 promoter hypermethylation trough enhancer of Zeste 2 (EZH2)-dependent trimethylation of histone 3 at lysine 27 [222], which results in no Id4 expression in highgrade cancers. Accordingly, whereas knockdown of Id4 supports the development of castration-resistant prostate cancer through constitutive activation of the androgen receptor [223], induced Id4 overexpression in highly malignant prostate cancer cells leads to apoptosis, decreased cell proliferation, migration and reduced tumor growth of subcutaneous xenografts [224]. These observations indicate that Id4 may act as a tumor suppressor, likely by binding Id1-3 with consequent reactivation of the E-protein-mediated DNA transcription [63] and/or by positive regulation of the expression and tumorsuppressor function of the androgen receptor [224]. However, it has been also reported that primary prostate cancers display high levels of Id4, which has been suggested to favor distant metastasis [225].

Caveolin-1, a cell membrane protein and positive regulator of cell survival and metastasis in prostate cancer, may interact with the helix-loop-helix domain of Id1. In prostate cancer cells this interaction plays an important role in epithelial-to-mesenchymal transition (EMT), it increases cell migration and taxol-induced apoptosis resistance through the activation of the Akt pathway [80]. Indeed, Id1 binding to caveolin-1 seems to improve the ability of the latter to bind and inhibit PP2A, which results in Akt activation [80].

\section{Cervical cancer}

Because of the correlation of Id1 expression and human papillomavirus (HPV)-induced cervical cancer, it is suggested, that Id1 also plays a role in HPV-related cervical carcinogenesis [226].

\section{Thyroid cancer}

In thyroid cancers the Id1 protein has been found to be overexpressed as an early target of TGF $\beta$. This correlates with the development of a mesenchymal phenotype with increased invasion capacity [227].

\section{Nasopharyngeal cancer}

Up-regulation of Id1, together with the p65 subunit of NF-kB, has been proposed to be a marker for poor prognosis in nasopharyngeal carcinoma. Accordingly, inhibition of Id1 and p65 with shRNA leads to downregulation of MMP9 and reduction of tumor cell migration [228].

\section{Colon cancer}

In colon cancers, which are mostly caused by mutations in the APC (adenomatous polyposis coli) gene and/or $\beta$ catenin genes, overexpression of Id 2 has been observed and attributed to Id2-promoter activation by upregulated $\beta$-catenin [114]. In primary colon cancer samples Id1 and Id3 regulate the self-renewal of colon cancer stem cells (CSCs) via p21. Id1/Id3 double knockout results in the lack of the tumor-initiating potential and increases the sensitivity of CSCs to the chemotherapeutic agent oxaliplatin [229].

\section{Colorectal cancer}

Colorectal cancer cells overexpressing the leukemia inhibitory factor (LIF) are associated with chemotherapeutic resistance through down-regulation of $\mathrm{p} 53$. This is mediated by Stat 3 activation, which in turn up-regulates Id1. The latter enhances MDM2 (mouse double minute 2 homolog), a key negative regulator of $\mathrm{p} 53$, leading to accelerated p53 degradation [120]. Also Id3 has been shown to promote colorectal tumorigenesis by inhibiting p21 [230]: indeed, Id3 is a downstream target of the Akt1/Smad5 pathway that is activated upstream by inflammation-induced up-regulation of the $\mathrm{Ca}^{2+}$ binding proteins calgranulin A and B (S100A8/9).

\section{Gastric cancer}

Gastric adenocarcinoma shows Id1 up-regulation, whereas the metastatic tumors express lower Id1 levels than the primary tumors, suggesting that Id1 may not be determinant for gastric cancer metastasis [231].

\section{Hepatocellular cancer (HCC)}

Id1 levels have been found to be high in HCC cells, whereas they are very low in normal liver tissues. Id1 overexpression, which is mediated by the MAPK/ERK pathway, is associated with increased c-Myc levels: indeed, Id1 knockdown leads to c-Myc reduction as well as c-Myc knockdown leads to Id1 reduction. Moreover, Id1 may interact directly with c-Myc without inhibiting the transcriptional activity of the latter [232].

Increased levels of Id1 have been also detected in tissue specimens from patients with cirrhosis without hepatocellular carcinoma and have been correlated with higher probability to develop the tumor [233].

\section{Pancreatic cancer}

The Id proteins are implicated in the tumorigenesis of human pancreatic cancer, a highly malignant cancer type. Id2 is overexpressed in the cancer cells of the pancreatic tumor mass, contributing to cancer cell growth that can be inhibited by Id2 antisense oligonucleotides [234]. Also Id1 has been found to be overexpressed in human pancreatic cancers, which is associated with 
enhanced tumor angiogenesis but not with poor prognosis [235].

\section{Neural cancers Glioblastoma multiforme (GBM)}

Glioblastoma multiforme (GBM) is the highest grade and most aggressive primary brain tumor. Id4 has been shown to inhibit glioma invasion in vitro by inhibiting MMP2 expression via an inhibitory interaction with Twist1 [236], a class II bHLH transcription factor that is highly expressed in GBM and is crucial for MMP2 expression [237, 238]. In addition, it has been shown that Id4 expression correlates with disease-free and overall survival of GBM patients [236]. In contrast, increased Id1-3 protein expression correlates with tumor vascularity, drug resistance and poor prognosis [239, 240]. Accordingly, Id1-silenced U87 GBM cells show significantly decreased proliferation and invasion capacity. Additionally, c-Myc, cyclin D1 and $\beta$-catenin expression decreases, while E-cadherin expression increases. As Ecadherin promotes mesenchymal-to-epithelial transition (MET), Id1 has been predicted to regulate the metastatic potential of GBM cells by supporting EMT [241].

High-grade glioma cells with high Id1 expression (but no Id2 and Id3 expression) show self-renewal capacity, whereas cells with low Id1 levels possess poor selfrenewal capacity but proliferative potential. Undifferentiated low-Id1 cells are characterized by high expression of progenitor-associated markers like Olig2. Interestingly, both Id1-high and Id1-low cell types are able to generate high-grade gliomas in mice, with faster tumor development and higher penetrance in the case of the low-Id1 cells. Moreover, mouse survival significantly improves upon Olig2 but not Id1 deletion, suggesting that non-self-renewal glioma cells may have high impact on tumor growth [242]. In the case of mesenchymal gliomas, all three Id proteins, Id1-3, are required for maintaining high-grade gliomas, whereas deletion of these three genes leads to tumor regression through release of glioma initiating cells (GICs) from the perivascular tumor niche, which is mediated by the inhibition of the master regulator of cell adhesion Rap1. Therefore, the interaction of GICs with endothelial cells is disrupted, which results in their loss of self-renewal and tumorforming capacity [243].

Recently, it has been shown that cancer stem cells and glioma aggressiveness are supported by a mechanism based on Id2 and the hypoxia-inducible factor $2 \alpha$ $(H I F 2 \alpha)$. Indeed, under hypoxia the unphosphorylated state of Id2 at Thr-27 is maintained upon inactivation of tyrosine-phosphorylation-regulated kinase 1 (Dyrk1). Unphosphorylated Id2 is able to bind the VHL-elongin$\mathrm{C}$ complex, thus disrupting the ubiquitin-ligase complex VCB-Cul2 (pVHL-elongin C-elongin B-Cullin-2), which results in HIF2 $\alpha$ stabilization by inhibition of its ubiquitination. This, in turn, leads to Id2 up-regulation, as HIF $2 \alpha$ is a positive transcriptional regulator of the $I d 2$ gene [82].

\section{Neuroblastoma}

In neuroblastoma, an extracranial cancer mostly occurring in infants and children and characterized by the amplification and overexpression of the oncogene $N-M y c$ (neuronal $M y c$ ) [244], Id2 is transcriptionally activated by Myc oncoproteins [115]. In turn, overexpression of Id2 abrogates pRb-induced cell-cycle arrest by direct binding to $\mathrm{pRb}[115,141,245]$. However, whether a correlation exists between N-Myc and Id2 gene/protein expression in neuroblastoma [246-250], or if the Myc action in vivo is mediated by Id2 in other cancer types like epidermal neoplasia [251] and lymphomagenesis [252] are still controversial and would need further investigation [141].

The four-and-a-half LIM-only protein 2 (FHL2) is able to interact with all four Id proteins through a relatively conserved region within the $\mathrm{N}$-terminal Id protein domains (C/S-L-S/A-E/D-S-L/V-A/G-I/G-S/A-R/A). After retinoic acid induced differentiation of neuroblastoma cells, FHL2 expression increases and counteracts the inhibitory effects of the Id proteins on E47, resulting in restored E47 induced transcription. Therefore, FHL2 is proposed to be a repressor of the oncogenic activity of Id2 in neuroblastoma [81].

Neuroblastoma cells are able to undergo reversible adaptive plasticity to survive and escape radio- or chemotherapy. One phenotype is highly proliferative and anchorage dependent (AD), the other is slow growing, anoikis-resistant and anchorage independent (AI) [253]. In the proliferating $\mathrm{AD}$ cells Id2 has been found to be 20-fold more expressed than in the AI cells (together with N-Myc, which would support Id2 being an effector of N-Myc [115, 245]), and it is suggested to support proliferation by antagonizing the TGF $\beta / \mathrm{Smad} 2 / 3$ pathway. Accordingly, Id2 down-regulation in $\mathrm{AD}$ cells activates the TGF $\beta$ pathway, resulting, however, not only in decreased proliferation and induction of apoptosis, but also in activation of anoikis-resistant pathways, similar to cells with the AI phenotype. Instead, overexpressed Id2 in $\mathrm{AI}$ cells leads to the proliferative $\mathrm{AD}$ phenotype, allowing the cells to survive unfavorable and stressful conditions. These observations suggest that Id2 plays a key role in reversible adaptive plasticity in neuroblastoma cells. Simultaneous targeting of the AD and AI phenotypes by using the chemotherapy agents doxorubicin and metformin and of the pathways responsible for reversible adaptive plasticity with LY2109761, a TGF $\beta$ receptor inhibitor, and sorafenib, a multi-kinase inhibitor, 
results in decreased tumor growth and prolonged survival in established mouse neuroblastoma tumors [254].

\section{Medulloblastoma}

In medulloblastoma the Id 2 and Id 3 proteins are overexpressed and promote tumor cell proliferation, whereas the Id1 protein has been found to be expressed in the tumor vessels, thus promoting tumor angiogenesis. In contrast, Id 4 has been detected neither in normal cerebellum nor in tumor cells [255].

\section{Leukemia}

\section{Acute myeloid leukemia (AML)}

Id2 and Id3 show different expression patterns and subcellular localization in acute leukemia subtypes: for example, AML is characterized by higher Id2 and Id3 expression than acute lymphoblastic leukemia (ALL) [256].

Overexpressed Id1 or Id3 are able to immortalize growth factor-dependent hematopoietic progenitors resulting in cells with an acute myeloid leukemia (AML)-like morphology and decreased $\mathrm{p} 15^{\mathrm{INK}}, \mathrm{p} 16^{\mathrm{INK} 4}$, $\mathrm{p} 19^{\mathrm{ARF}}$ and $\mathrm{p} 21^{\mathrm{Cip} 1}$ in vitro. In vivo Id1 overexpression leads to lethal myeloproliferative disease [257]. Id1 and Id 2 mRNA levels are associated with AML, whereby patients with increasing $I d 1$ levels correlate with poor clinical outcome. Microarray analysis suggests that $I d 1$ and Id2 gene expression might be induced downstream of multiple signal transduction pathways of mutationally activated oncogenic tyrosine kinases like FLT3, TELABL, BCR-ABL and PDGFRB [119, 258].

Down-regulated Id2 and up-regulated E2-2 have been observed in mixed lineage leukemia (MLL)-rearranged AML, which supports leukemia stem cell potential and confer poor prognosis. This suggests that Id2 might have a tumor suppressor role in MLL-rearranged AML as well as in $\mathrm{t}(8 ; 21)$ AML [259].

Id4 methylation plays an important role in disease progression in patients with myelodysplastic syndrome (MDS) that is a myeloid hematopoietic malignant disorder with high susceptibility to transform into AML. High levels of $I d 4$ methylation have been correlated with decreased survival [260].

\section{Chronic lymphocytic leukemia (CLL)}

Id2 and Id3 support survival of CLL cells, probably by inhibiting pro-apoptotic pathways. Moreover, the CLL cells with high Id3 and, to a lesser extent, Id2 levels display high chemoresistance [261].

\section{Chronic myeloid leukemia (CML)}

In CML Id4-promoter methylation increases during disease progression from the chronic to the accelerated phase and blast crisis [262]. The crucial role of Id4 has been proven with haploid loss of Id4 in non-transformed TCL1-positive B cells, leading to enhanced B-cell proliferation and decrease in dexamethasone-mediated apoptosis [263].

\section{Lymphoma}

Id2 is overexpressed in Hodgkin lymphoma tumor cells and suppresses the expression of B cell specific genes [264]. Id4 methylation has been found to be high in lymphoma tissues, whereas no methylation has been detected in control tissues. Moreover, high Id4 methylation correlates with decreased survival $[265,266]$. In Burkitt lymphoma missense mutations of $I d 3$ have been found, which lead to mutated HLH domain and altered ability of Id3 to inhibit TCF3 and/or TCF4 [199]. Accordingly, Id 3 mutations have been observed in more than $50 \%$ of all Burkitt lymphomas, and the presence of $I d 3$ and/or TCF3 mutations has been detected in $70 \%$ of sporadic Burkitt lymphomas. The Id3 destructive and/or the TCF3 activating mutations lead to TCF3 activated transcription resulting in pro-survival phosphoinositide 3kinase (PI3K) signaling [267]. These results indicate that Id3 inactivating mutations, together with IG-Myc translocation, are characteristic properties of Burkitt lymphoma pathogenesis [199].

\section{The role of the Id1 isoform in cancer}

While there are many studies about the role of Id 1 in cancer development and progression, much less is known about the Id1 isoform generated by alternative splicing. In contrast to the crucial role of Id1 in cancer, overexpression of its isoform in lung and prostate cancer cells leads to cell-growth arrest, tumor shrinkage, impaired angiogenesis and sensitization to radiotherapyinduced cell death [36]. Furthermore, unlike Id1 that promotes cell proliferation, its isoform causes a cancer stem cell-like phenotype and promotes its self-renewal. This would support a role of Id1 and its isoform in tumor initiation by promoting self-renewal properties by the spliced Id1 variant and, subsequently, proliferation by canonical Id1 [35].

\section{The role of Id4 in cancer}

In various human tumor types such as acute and chronic leukemia [268], different malignant lymphomas [265, 266, 269], colorectal carcinoma [270], breast cancer [271] and gastric carcinoma [272], the tumor suppressor activity of Id4 is abrogated through epigenetic inactivation of its promoter by methylation during cancer development. These findings would suggest that Id4 gene methylation degree might be used as a tumor marker. However, the role of Id4 in breast cancer remains controversial [273]: indeed, Id4 has been detected in breast cancer cells expressing 
p53 mutants, promoting tumor neo-angiogenesis [111], as well as in tamoxifen-refractory breast cancer, thus supporting chemoresistance [274].

\section{The role of the Id proteins in cancer metabolism}

A crucial event of cancer development and progression is the metabolic reprogramming of cancer cells to cover their high glucose requirements. This takes place under control of oncogenic signaling pathways and several mutations occurring in cancer [275, 276]. For example, cMyc seems to be one of the main regulators of aerobic glycolysis and glutaminolysis [277]. It has been shown that Id1 and c-Myc positively regulate each other's expression in hepatocellular carcinoma cells and promote c-Myc-mediated glycolysis under aerobic conditions. Instead, under anaerobic conditions glycolysis is promoted by the hypoxia-inducible factor $1 \alpha$ (HIF $1 \alpha)$ that recruits Mxi1, a transcriptional suppressor of Id1 and c-Myc, thus leading to down-regulation of Id1 and c-Myc expression [232].

\section{The role of the Id proteins in tumor angiogenesis and metastasis}

Prerequisite for tumor progression and metastasis is a sufficient blood supply guaranteed by the formation of new blood vessels (tumor angiogenesis). The initiation of angiogenesis in tumors is triggered by the up-regulation of VEGF that promotes the exponential growth of the tumor. Like in neoangiogenesis during normal development, the Id proteins play a role also in tumor neoangiogenesis [149, 185]. Accordingly, Id1 $+/-$ Id3-/- mice fail to grow tumors due to poor vascularization and necrosis [149].

Matrix metalloproteinases (MMPs) are zinc-dependent endopeptidases that mediate membrane degradation and cell migration. Id1, Id 2 and Id 3 may increase MMP gene expression, leading to tumor cell invasion. High levels of Id1 and the membrane-type 1-MMP (MT1-MMP) [209] or MMP1 [278] have been associated to breast cancer metastasis. In melanoma, the Id1-induced up-regulation of MMP2 is mediated by the adhesion molecule MUC18. MUC18 positively regulates Id1 expression through the modulation of ATF3, contributing to melanoma metastasis. Indeed, silencing of MUC18 leads to increased ATF3 binding to the $I d 1$ promoter, which results in Id1 down-regulation [279].

The zinc-finger protein KLF17 is a metastasis suppressor by inhibition of $I d 1$ transcription upon binding to its promoter region. KFL17 is significantly down-regulated in primary human breast cancer samples. Therefore, its suppression leads to Id1 induction, which might promote primary tumor vascularization via VEGF production, breast cancer cell invasion and EMT [280]. Id2 also seems to play a crucial role in tumor cell migration and invasion: indeed, c-Myc up-regulation and subsequent Id 2 overexpression in highly metastatic human tumor cell lines lead to down-regulation of semaphorin $3 \mathrm{~F}$ (SEMA3F) that is a potent metastasis inhibitor and a direct target gene of the E47/Id2 pathway [281, 282].

In colorectal cancer it has been shown that hypoxia, a common feature of solid tumors, may increase the cancer stem cells (CSCs) subpopulations as well as promote cancer metastasis. The proposed mechanism relies on the hypoxia-mediated activation of the $\mathrm{Wnt} / \beta$-catenin signaling that leads to Id2 overexpression that, in turn, induces a CSCs phenotype and expression of MMP2 and MMP9 responsible for increased cell migration [283].

There is growing evidence that phenotypic plasticity, in particular the epithelia-to-mesenchymal and mesenchymal-to-epithelial transition switch (EMTMET), is required for effective cancer metastasis [284]. In breast cancer Id1 plays a crucial role in phenotype switching during lung metastasis [285, 286]. TGF $\beta$ induced overexpression of Id1 is necessary not only to obtain tumor-initiating cells at the primary site, but also to switch the EMT phenotype, which is induced by the zinc finger transcription factor Snail at the primary site, back to the MET one at the colonization site. It has been shown that Id1 may induce the EMT-to-MET switch at the distant site by antagonizing Twist1, but not at the primary site, where the EMT phenotype is maintained by the presence of Snail [285].

\section{Id proteins and chemotherapeutic drug resistance}

Chemotherapeutic drugs function by inducing cell death in cancer cells. A limitation of chemotherapy is the drug resistance that is associated with a more aggressive cancer disease and the resistance to further chemotherapeutic treatments. Factors positively affecting multi-drug resistance include up-regulation of the multi-drug transporter P-glycoprotein [287], and of the inhibitor of apoptosis Bcl2 [288], as well as activation of the Raf-1/MAPK [289] and NF-kB [290] pathways, and inactivation of the c-Jun N-terminal kinase (JNK) pathway [291]. Based on the fact that Id1 can activate the Raf-1/MAPK and NF$\kappa B$ pathways [140, 292], a role of Id 1 in the development of drug resistance has been suggested.

In prostate cancer $\mathrm{Bcl} 3$ is overexpressed via IL6, leading to the up-regulation of Id1 and Id2, and inducing resistance against anticancer drugs. Accordingly, $\mathrm{Bcl} 3$ knockdown results in decreased Id1 and Id 2 expression, with tumor cells becoming more sensitive to chemotherapeutic drug-induced apoptosis [118]. REIC/Dickkopf-3 (Dkk-3) is a tumor suppressor that is reduced in numerous human cancers. Overexpression of REIC/Dkk-3 in malignant mesothelioma (MM) down-regulates Id1 expression via activation of ATF3 and Smad, resulting in enhanced JNK phosphorylation and REIC/Dkk-3- 
induced apoptosis [293]. In contrast, ectopic Id1 expression induces resistance to taxol treatment in breast, prostate and nasopharyngeal carcinoma cells [294-296]. Hence, increased sensitivity to taxol-mediated JNK activation and apoptosis in prostate cancer could be reached by using small RNA interfering technology to downregulate Id1 [297].

Besides resistance against taxol, Id1 seems to induce resistance also against other antitumor agents including doxorubicin, cyclophosphamide [298] and epirubicin [299], which suggests that Id1 promotes cell survival by acting as universal antiapoptotic factor [300]. These results provide a linkage between up-regulation of the Id proteins and poor prognosis and severity of some human cancer types.

Id1 overexpression shows not only high correlation with tumor invasion, metastasis and poor prognosis in esophageal squamous cell carcinoma (ESCC), but it also plays a crucial role in the resistance to the anticancer drugs etoposide [301] and 5-fluorouracil (5-FU) [302]: indeed, etoposide enhances c-Jun/c-Fos expression that leads to $I d 1$ gene transcription and expression, resulting in inhibition of apoptosis [301]. 5-FU chemoresistance is accompanied by up-regulated expression of Id1, insulin-like growth factor 2 (IGF2) and the transcription factor E2F1. Id1 inhibits E2F1 degradation by binding to Cdc20. In turn, E2F1 binds to the IGF2 promoter and activates its transcription. IGF2 increases phosphorylated-Akt and its downstream target thymidylate synthase, which abolishes 5-FUinduced apoptosis [302].

Treatment of hepatocellular carcinoma cells with the antitumor drug sodium butyrate $(\mathrm{NaB})$, a histone deacetylase (HDAC) inhibitor, has shown dependency from the Id2 expression: indeed, $\mathrm{NaB}$-mediated induction of anti-apoptotic $\mathrm{Bcl} 2$ is inhibited by Id2 knockdown but it is supported by $\mathrm{Id} 2$ overexpression. Therefore, the Id 2 level has been suggested to serve as prognostic marker for clinical response to HDAC inhibitors [303].

Glioma stem cells (GSCs) are relatively resistant to chemotherapy and irradiation. Id4 has been shown to suppress miR-9 and induce SOX2. Enhanced SOX2 expression leads to induction of ATP-binding cassette $(\mathrm{ABC})$ transporters 3 and 6 , resulting in chemoresistance of GSCs. Furthermore, elevated SOX2 expression dedifferentiates astrocytes and glioma cells to GSCs [304].

\section{The Id proteins as therapeutic targets}

Cancer diseases are one of the most frequent causes of death in developed countries and require the constant research of novel, potent anti-tumor therapeutics. The Id proteins represent interesting targets for such purpose, as they are involved in cellular key events related both to tumorigenesis and cancer progression [149, 201, 305].
Different approaches to reduce aberrant Id-protein levels and restore differentiation of hyperproliferative cells have been successfully applied. For example, by treating human metastatic breast cancer cells with an Id1 antisense oligonucleotide not only Id1 decreases, but also MT1-MMP. Therefore, the significantly reduced breast cancer metastasis to the lung might be a result of reduced MT1-MMP-mediated invasiveness [209].

Furthermore, targeting Id1 with Id1-siRNA in adenoid cystic carcinoma (ACCM) mouse models inhibits tumor growth, reduces tumor cell proliferation/invasion and induces apoptosis [306].

An Id1 antisense oligonucleotide conjugated to a peptide that addresses tumor neovessels specifically has been used to decrease the growth rate of breast tumors and the highly aggressive Lewis Lung carcinomas (LLCs). Moreover, the metastatic growth of LLCs could be delayed. This antitumor effect enhances upon combination with the Hsp90 inhibitor 17-AAG [307].

MicroRNAs (miRNAs) are a class of small, noncoding RNAs that regulate gene expression and differentiation by interacting with mRNAs. Retinoic acid-induced up-regulation of two miRNAs (miR-9 and miR-103) during neuroblastoma cell differentiation inhibits Id2 expression and cell growth. Therefore, these two miRNAs may have tumor suppressive properties in several neural tumors [308].

In metastatic breast cancer, glioblastoma and salivary gland cancer cannabidiol, a low toxic cannanbinoid, has been shown to reduce Id1 expression, resulting in less tumor growth, aggressiveness and metastasis [309-311].

The influence of MK615, an extract from the Japanese apricot "Prunus mume" known for antitumorigenic and antiinflammatory effects, has been studied in human malignant melanoma cells: MK615 reduces Id1 expression and, therefore, cell growth through the inhibition of the ERK1/2 pathway [312].

Curcumin significantly down-regulates mRNA and protein levels of Id1 in prostate cancer cells and xenografted tumors, which is accompanied by induction of apoptosis and tumor growth suppression [313].

Berberine, an isoquinoline alkaloid present in different herbs, including barberry, has shown anti-proliferative and anti-metastatic effects in hepatocellular carcinoma mice via Id1 down-regulation at the transcriptional level. Indeed, berberine may inhibits the $I d 1$ promoter activity, resulting in suppression of cellular growth, invasiveness and VEGF secretion [314].

An arabinogalactan polysaccharide from the Panax notoginseng ( $\mathrm{RN} 1$ ) has been able to inhibit microvessel formation in pancreatic cancer-cell xenograft tumors in nude mice through the inhibition of BMP2/Smad-induced Id1 expression [315]. 
2-Methoxyestradiol, a metabolite of $17-\beta$-estradiol, may inhibit angiogenesis and reduce tumor growth at late stages through enhanced apoptosis. This correlates with the inhibition of Id1 in mouse and human breast cancer cell lines [316]. In gastric cancer cells, Id1 could be dose-dependently decreased by sulindac sulfide, a non-steroidal anti-inflammatory drug [317]. Furthermore, treatment with epigallocatechin-3-gallate, a catechin from tea, down-regulates Id1 mRNA and protein in poorly differentiated AGS gastric cancer cells [318].

TGF $\beta$, Id1 and CD44 regulate glioma stem cells, which are responsible for glioblastoma initiation, relapse, and therapeutic resistance. Treating patient-derived glioblastoma specimens with LY2109761, a TGF $\beta$ receptor type I and II dual antagonist, leads to the reduction of $\mathrm{CD} 44^{\text {high }} / \mathrm{Id} 1^{\text {high }}$ glioma stem cells, thus preventing tumor initiation and recurrence [109].

USP1 is up-regulated by PDGF via E2F. This signal stabilizes Id2 expression that is crucial for glioma survival. Pimozide, an anti-psychotic drug and USP1 inhibitor, might have therapeutic activity in patients with proneural PDGF-driven glioblastoma. Indeed, pimozide suppresses Id2 expression and reduces tumor growth [319].

Furthermore, chemosensitivity of human U87 GBM cells may be enhanced by silencing $I d 2$. Indeed, the antiproliferative effect of the anti-tumor agents semustine, teniposide and temozolomide is higher in Id2-silenced cells than in Id2-expressing cells. As Id2-silenced cells express higher levels of caspase-3, it is likely that their increased chemosensitivity is due to the up-regulation of pro-apoptotic pathways [240].

Src tyrosine kinase is suggested to promote tumor aggressiveness through BMP2-induced Id1 expression. Accordingly, Id1 levels are reduced in breast, prostate, lung and colon cancer cell lines treated with the smallmolecule Src inhibitor AZD0530 [320].

PI3K/Akt signaling is a downstream component of Id1 and promotes osteosarcoma progression. Accordingly, the PI3K inhibitor LY294002 decreases Id1-induced osteosarcoma tumor growth [321].

Inhibition of BMP signaling by the small molecule DMH2 that binds BMP type I receptors has led to decrease in Id proteins and suppression of growth of cancer cells expressing stem cell markers [322].

The DNA-damaging agents camptothecin and adriamycin are able to inhibit Id1 expression trough wildtype p53 induced DEC1 that binds to the Id 1 promoter and represses its transcription [138].

Recently, a small molecule (AGX51) that directly targets the Id proteins has been discovered, which blocks tumor angiogenesis and is currently in the preclinical phase for drug development [323, 324]. In addition, peptide-based molecules have been developed to bind the Id proteins and inhibit their function. A peptide aptamer (Id1/Id3-PA7) has been developed, which induces cell cycle arrest and apoptosis in ovarian and breast cancer cells by inhibition of Id1 and Id3 [325, 326]. A modified HEB HLH domain has been shown to interfere with and inhibit Id2 in human neuroblastoma cells. This has led to the activation of the cell-cycle inhibitor p $27^{\text {Kip1 }}$ with induction of growth arrest and neural differentiation [327, 328]. Short peptides based on MyoD [329] or Id [57, 330] HLH sequences have been designed, which bind the Id proteins in the low-micromolar range and are able to inhibit proliferation of cancer cells and of a vascular smooth muscle cell phenotype.

A T-cell mediated vaccine approach has been recently tested in mouse neuroblastoma. Id2-knockdown neuroblastoma cells (Id2kd-Neuro2a) have shown to be immunogenic. These cells do not grow in immunecompetent mice that even develop immunity against wildtype neuroblastoma cells. In contrast, Id2kd-Neuro2a cells grow aggressively in immune-compromised mice. In combination with the use of an antibody against the cytotoxic T lymphocyte antigen-4 (CTLA-4), an inhibitor of T-cell responses, vaccination with Id2kd-Neuro2a cells of mice bearing established neuroblastoma tumors has been shown not only to suppress the tumor growth but also to eradicate the tumor itself [331].

A nanoparticle-based approach has been recently used to deliver recombinant Id4 protein as a biotherapeutic agent into prostate cancer cells or into prostate cancers in mice. Indeed, $I d 4$ expression is epigenetically silenced in prostate cancer, whereas its ectopic expression suppresses the cancer phenotype. Accordingly, delivery of Id4 encapsulated in biodegradable polycaprolactone/ maltodextrin nanoparticles leads to increased apoptosis, decreased proliferation and colony formation. In vivo the Id4-nanoparticle approach has been shown to be more efficient than the administration of docetaxel in reducing the tumor volume [332].

\section{Conclusions}

The Id proteins exert their function by interacting with and modulating key regulators of the cell cycle. The four members of the Id family show distinct expression patterns and, despite the high homology of their HLH domains, display different protein-protein interaction preferences both under physiological and pathological conditions. This suggests that, on the one hand, the structure of the Id HLH domain is fine-tuned and that, on the other hand, the non-conserved $\mathrm{N}$-terminal and C-terminal domains are determinant for the specific protein binding profile of each Id protein. Although the main mechanism of the Id proteins rely on the direct interaction and modulation of bHLH factors, the data reported in the literature and partly summarized in this 
review clearly show that the mode of action of these four small proteins is highly complex. This is due to their ability to interact with a multiplicity of proteins that belong to different families and affect different cellular pathways. Strikingly, such functional diversity reflects the structural flexibility of the Id proteins that, in fact, contain high degree of disorder. Obviously, this significant structural and functional diversity makes the Id proteins a challenging topic of research; however, the successful work done so far encourages to continue the exploration of the biology and structure of these intriguing protein regulators, with the aim to understand and solve controversial data, to answer still open questions, to further validate them as targets for tumor diagnostics and therapy, and to develop drug-like molecules for their detection and inhibition in vivo.

\begin{abstract}
Abbreviations
AML: Acute myeloid leukemia; Bcl: B-cell leukemia; bHLH: basic-HLH; CRMP1: Chromosome region maintenance protein 1; CSC: Cancer stem cell; CSN: COP9 signalosome; EMT: Epithelial-to-mesenchymal transition; ENH: Enigma homolog protein; EZH2: Enhancer of Zeste 2; FHL2: Four-and-ahalf LIM-only protein 2; GBM: Glioblastoma multiforme; GSC: Glioblastomaderived stem cell; H3K9ac: Acetylation of histone $\mathrm{H3}$ at lysine 9; H3K9me2: Dimethylation of histone H3 at lysine 9; HBX: Hepatitis B virusencoded protein X; HIF: Hypoxia-inducible factor; Id: Inhibitor of DNA binding and cell differentiation; IG: Immunoglobulin; LIF: Leukemia inhibitory factor; MAPK: Mitogen-activated protein kinase; MDM2: Mouse double minute 2 homolog; MET: Mesenchymal-to-epithelial transition; MLL: Mixed lineage leukemia; MMP: Matrix metalloproteinase; MT1-MMP: Membrane-type 1 MMP; NES: Nuclear export signal; NF-Y: Nuclear factor Y; NLS: Nuclear localization signal; NMR: Nuclear magnetic resonance; PAS: Per-ARNT-SIM; PDGF: Platelet-derived growth factor; PSA: Kallikrein3/prostate specific antigen; PSAP: Prostate acid phosphatase; PTEN: Phosphatase and tensin homolog deleted on chromosome 10; S100A8: $\mathrm{Ca}^{2+}$ binding protein calgranulin A; SCC: Squamous cell carcinoma; TCF: T-cell factor; TCR: T-cell receptor; TNF: Tumor necrosis factor
\end{abstract}

\section{Acknowledgements}

CC kindly thanks the Land Salzburg for funding.

\section{Availability of data and materials}

Not applicable.

\section{Authors' contributions}

CC designed the manuscript. CR and CC wrote the manuscript. CC prepared the figures. Both read and accepted the final version of the manuscript.

\section{Competing interests}

The authors declare that they have no competing interests.

\section{Consent for publication}

Not applicable.

Ethics approval and consent to participate

Not applicable.

Received: 2 September 2016 Accepted: 29 December 2016

Published online: 25 January 2017

\section{References}

1. Desprez PY, Sumida T, Coppé JP. Helix-loop-helix proteins in mammary gland development and breast cancer. J Mammary Gland Biol Neoplasia. 2003:8:225-39.

2. Massari ME, Murre C. Helix-loop-helix proteins: regulators of transcription in eucaryotic organisms. Mol Cell Biol. 2000;20:429-40.
3. Murre C, Bain G, van Dijk MA, Engel I, Furnari BA, Massari ME, Matthews JR, Quong MW, Rivera RR, Stuiver MH. Structure and function of helix-loop-helix proteins. Biochim Biophys Acta. 1994;1218:129-35.

4. Cano A, Portillo F. An emerging role for class I bHLH E2-2 proteins in EMT regulation and tumor progression. Cell Adhes Migr. 2010;4:56-60.

5. Murre C, McCaw PS, Vaessin H, Caudy M, Jan LY, Jan YN, et al. Interactions between heterologous helix-loop-helix proteins generate complexes that bind specifically to a common DNA sequence. Cell. 1989;58:537-44.

6. Yokoyama S, Asahara H. The myogenic transcriptional network. Cell Mol Life Sci. 2011;68:1843-9.

7. Amati B, Brooks MW, Levy N, Littlewood TD, Evan Gl, Land H. Oncogenic activity of the c-Myc protein requires dimerization with Max. Cell. 1993;72: 233-45.

8. Dang CV. MYC on the path to cancer. Cell. 2012;149:22-35.

9. Hemesath TJ, Steingrimsson E, McGill G, Hansen MJ, Vaught J, Hodgkinson CA, Arnheiter H, Copeland NG, Jenkins NA, Fisher DE. Microphthalmia, a critical factor in melanocyte development, defines a discrete transcription factor family. Genes Dev. 1994:8:2770-80.

10. Kuiper RP, Schepens M, Thijssen J, Schoenmakers EF, van Kessel AG. Regulation of the MiTF/TFE bHLH-LZ transcription factors through restricted spatial expression and alternative splicing of functional domains. Nucleic Acids Res. 2004;32:2315-22.

11. Zhao GQ, Zhao Q, Zhou X, Mattei MG, de Crombrugghe B. TFEC, a basic helix-loop-helix protein, forms heterodimers with TFE3 and inhibits TFE3dependent transcription activation. Mol Cell Biol. 1993;13:4505-12.

12. Kewley RJ, Whitelaw ML, Chapman-Smith A. The mammalian basic helixloop-helix/PAS family of transcriptional regulators. Int J Biochem Cell Biol. 2004;36:189-204.

13. Kageyama R, Ohtsuka T, Kobayashi T. The Hes gene family: repressors and oscillators that orchestrate embryogenesis. Development. 2007;134:1243-51.

14. Sasai $Y$, Kageyama R, Tagawa $Y$, Shigemoto R, Nakanishi S. Two mammalian helix-loop-helix factors structurally related to Drosophila hairy and Enhancer of split. Genes Dev. 1992;6:2620-34.

15. Benezra R, Davis RL, Lockshon D, Turner DL, Weintraub H. The protein Id: a negative regulator of helix-loop-helix DNA binding proteins. Cell. 1990;61: 49-59.

16. Ruzinova MB, Benezra R. Id proteins in development, cell cycle and cancer. Trends Cell Biol. 2003:13:410-8.

17. Sikder HA, Devlin MK, Dunlap S, Ryu B, Alani RM. Id proteins in cell growth and tumorigenesis. Cancer Cell. 2003;3:525-30.

18. Ferre-D'Amare AR, Prendergast GC, Ziff EB, Burley SK. Recognition by Max of its cognate DNA through a dimeric b/HLH/Z domain. Nature. 1993;363:38-45.

19. Blackwell TK, Kretzner L, Blackwood EM, Eisenman RN, Weintraub H. Sequence-specific DNA binding by the c-Myc protein. Science. 1990;250: 1149-51.

20. Blackwell TK, Weintraub H. Differences and similarities in DNA-binding preferences of MyoD and E2A protein complexes revealed by binding site selection. Science. 1990;250:1104-10.

21. Murre C, McCaw PS, Baltimore D. A new DNA binding and dimerization motif in immunoglobulin enhancer binding, daughterless, MyoD, and myc proteins. Cell. 1989;56:777-83.

22. Sato Y. Role of ETS family transcription factors in vascular development and angiogenesis. Cell Struct Funct. 2001;26:19-24.

23. Jen $Y$, Weintraub $H$, Benezra R. Overexpression of Id protein inhibits the muscle differentiation program: in vivo association of Id with E2A proteins. Genes Dev. 1992;6:1466-79.

24. Christy BA, Sanders LK, Lau LF, Copeland NG, Jenkins NA, Nathans D. An Idrelated helix-loop-helix protein encoded by a growth factor-inducible gene. Proc Natl Acad Sci U S A. 1991;88:1815-9.

25. Riechmann V, van Cruchten I, Sablitzky F. The expression pattern of Id4, a novel dominant negative helix-loop-helix protein, is distinct from Id 1, Id2 and Id3. Nucleic Acids Res. 1994:22:749-55.

26. Sun $\mathrm{XH}$, Copeland NG, Jenkins NA, Baltimore D. Id proteins Id 1 and Id2 selectively inhibit DNA binding by one class of helix-loop-helix proteins. Mol Cell Biol. 1991;11:5603-11.

27. Campuzano S. Emc, a negative HLH regulator with multiple functions in Drosophila development. Oncogene. 2001;20:8299-307.

28. Liu KJ, Harland RM. Cloning and characterization of Xenopus Id4 reveals differing roles for Id genes. Dev Biol. 2003;264:339-51.

29. Mathew S, Chen W, Murty W, Benezra R, Chaganti RS. Chromosomal assignment of human ID1 and ID2 genes. Genomics. 1995;30:385-7. 
30. Nehlin JO, Hara E, Kuo WL, Collins C, Campisi J. Genomic organization, sequence, and chromosomal localization of the human helix-loop-helix Id1 gene. Biochem Biophys Res Commun. 1997;231:628-34.

31. Deed RW, Hirose T, Mitchell EL, Santibanez-Koref MF, Norton JD. Structural organisation and chromosomal mapping of the human Id-3 gene. Gene. 1994;151:309-14.

32. Ellmeier W, Aguzzi A, Kleiner E, Kurzbauer R, Weith A. Mutually exclusive expression of a helix-loop-helix gene and $\mathrm{N}$-myc in human neuroblastomas and in normal development. EMBO J. 1992;11:2563-71.

33. Pagliuca A, Bartoli PC, Saccone S, Della Valle G, Lania L. Molecular cloning of ID4, a novel dominant negative helix-loop-helix human gene on chromosome 6p21.3-p22. Genomics. 1995;27:200-3.

34. Hernandez MC, Andres-Barquin PJ, Israel MA. Molecular cloning of the cDNA encoding a helix-loop-helix protein, mouse ID1B: tissue-specific expression of ID1A and ID1B genes. Biochim Biophys Acta. 1996;1308:28-30.

35. Manrique I, Nguewa P, Bleau AM, Nistal-Villan E, Lopez I, Villalba M, Gil-Bazo I, Calvo A. The inhibitor of differentiation isoform Id1b, generated by alternative splicing, maintains cell quiescence and confers self-renewal and cancer stem cell-like properties. Cancer Lett. 2015;356:899-909.

36. Nguewa P, Manrique I, Diaz R, Redrado M, Parrondo R, Perez-Stable C, Calvo A. Id-1B, an alternatively spliced isoform of the inhibitor of differentiation-1, impairs cancer cell malignancy through inhibition of proliferation and angiogenesis. Curr Mol Med. 2014;14:151-62.

37. Springhorn JP, Singh K, Kelly RA, Smith TW. Posttranscriptional regulation of Id1 activity in cardiac muscle. Alternative splicing of novel Id1 transcript permits homodimerization. J Biol Chem. 1994;269:5132-6.

38. Tamura Y, Sugimoto M, Ohnishi K, Sakai T, Hara E. Differential activity of a variant form of the human Id-1 protein generated by alternative splicing. FEBS Lett. 1998:436:169-73.

39. Deed RW, Jasiok M, Norton JD. Attenuated function of a variant form of the helix-loop-helix protein, Id-3, generated by an alternative splicing mechanism. FEBS Lett. 1996:393:113-6.

40. Forrest ST, Barringhaus KG, Perlegas D, Hammarskjold ML, McNamara CA. Intron retention generates a novel ld3 isoform that inhibits vascular lesion formation. J Biol Chem. 2004;279:32897-903.

41. Beisswenger M, Yoshiya T, Kiso Y, Cabrele C. Synthesis and conformation of an analog of the helix-loop-helix domain of the Id1 protein containing the O-acyl iso-prolyl-seryl switch motif. J Pept Sci. 2010;16:303-8.

42. Colombo N, Cabrele C. Synthesis and conformational analysis of Id2 protein fragments: impact of chain length and point mutations on the structural HLH motif. J Pept Sci. 2006;12:550-8.

43. Kiewitz SD, Cabrele C. Synthesis and conformational properties of protein fragments based on the Id family of DNA-binding and cell-differentiation inhibitors. Biopolymers. 2005;80:762-74.

44. Kiewitz SD, Kakizawa T, Kiso Y, Cabrele C. Switching from the unfolded to the folded state of the helix-loop-helix domain of the Id proteins based on the O-acyl isopeptide method. J Pept Sci. 2008;14:1209-15.

45. Pesce S, Benezra R. The loop region of the helix-loop-helix protein Id1 is critical for its dominant negative activity. Mol Cell Biol. 1993;13:7874-80.

46. Deed RW, Hara E, Atherton GT, Peters G, Norton JD. Regulation of Id3 cell cycle function by Cdk-2-dependent phosphorylation. Mol Cell Biol. 1997;17:6815-21.

47. Forrest ST, Taylor AM, Sarembock IJ, Perlegas D, McNamara CA. Phosphorylation regulates Id3 function in vascular smooth muscle cells. Circ Res. 2004:95:557-9.

48. Hara E, Hall M, Peters G. Cdk2-dependent phosphorylation of Id2 modulates activity of E2A-related transcription factors. EMBO J. 1997;16:332-42.

49. Nishiyama K, Takaji K, Uchijima Y, Kurihara Y, Asano T, Yoshimura M, Ogawa $\mathrm{H}$, Kurihara $\mathrm{H}$. Protein kinase A-regulated nucleocytoplasmic shuttling of Id1 during angiogenesis. J Biol Chem. 2007;282:17200-9.

50. Lasorella A, Stegmuller J, Guardavaccaro D, Liu G, Carro MS, Rothschild G, de la Torre-Ubieta L, Pagano M, Bonni A, lavarone A. Degradation of Id2 by the anaphase-promoting complex couples cell cycle exit and axonal growth. Nature. 2006;442:471-4.

51. Kurooka H, Yokota Y. Nucleo-cytoplasmic shuttling of Id2, a negative regulator of basic helix-loop-helix transcription factors. J Biol Chem. 2005;280:4313-20.

52. Liu J, Shi W, Warburton D. A cysteine residue in the helix-loop-helix domain of Id 2 is critical for homodimerization and function. Biochem Biophys Res Commun. 2000;273:1042-7.

53. Svobodova J, Cabrele C. Stepwise solid-phase synthesis and spontaneous homodimerization of the helix-loop-helix protein Id3. Chembiochem. 2006; 7:1164-8.
54. Wibley J, Deed R, Jasiok M, Douglas K, Norton J. A homology model of the Id-3 helix-loop-helix domain as a basis for structure-function predictions. Biochim Biophys Acta. 1996;1294:138-46.

55. Wong MV, Jiang S, Palasingam P, Kolatkar PR. A divalent ion is crucial in the structure and dominant-negative function of ID proteins, a class of helixloop-helix transcription regulators. PLoS One. 2012;7:e48591.

56. Eletsky A, Wang D, Kohan E, Janjua H, Acton TB, Xiao R, Everett JK, Montelione GT, Szyperski T. Solution NMR structure of the helix-loop-helix domain of human ID3 protein, Northeast Structural Genomics Consortium Target HR3111A. 2011. doi:10.2210/pdb2lfh/pdb.

57. Beisswenger $M$, Cabrele C. Self-recognition behavior of a helix-loop-helix domain by a fragment scan. Biochim Biophys Acta. 2014;1844:1675-83.

58. Linding R, Jensen LJ, Diella F, Bork P, Gibson TJ, Russell RB. Protein disorder prediction: implications for structural proteomics. Structure. 2003;11:1453-9.

59. Obradovic Z, Peng K, Vucetic S, Radivojac P, Dunker AK. Exploiting heterogeneous sequence properties improves prediction of protein disorder. Proteins. 2005;61 Suppl 7:176-82.

60. Wong MV, Palasingam P, Kolatkar PR. Cloning, purification and preliminary X-ray data analysis of the human ID2 homodimer. Acta Crystallogr Sect F: Struct Biol Cryst Commun. 2012;68:1354-8.

61. Langlands K, Yin X, Anand G, Prochownik EV. Differential interactions of Id proteins with basic-helix-loop-helix transcription factors. J Biol Chem. 1997; 272:19785-93.

62. Samanta J, Kessler JA. Interactions between ID and OLIG proteins mediate the inhibitory effects of BMP4 on oligodendroglial differentiation. Development. 2004;131:4131-42.

63. Sharma P, Chinaranagari S, Chaudhary J. Inhibitor of differentiation 4 (ID4) acts as an inhibitor of ID-1, -2 and -3 and promotes basic helix loop helix (bHLH) E47 DNA binding and transcriptional activity. Biochimie. 2015;112: 139-50.

64. lavarone A, Garg P, Lasorella A, Hsu J, Israel MA. The helix-loop-helix protein Id-2 enhances cell proliferation and binds to the retinoblastoma protein. Genes Dev. 1994;8:1270-84.

65. Lasorella A, lavarone A, Israel MA. Id2 specifically alters regulation of the cell cycle by tumor suppressor proteins. Mol Cell Biol. 1996;16:2570-8.

66. Lasorella A, lavarone A. The protein ENH is a cytoplasmic sequestration factor for Id2 in normal and tumor cells from the nervous system. Proc Natl Acad Sci U S A. 2006:103:4976-81.

67. Nakatani M, Ito J, Koyama R, lijima M, Yoshimoto N, Niimi T, Kuroda S, Maturana AD. Scaffold protein enigma homolog 1 overcomes the repression of myogenesis activation by inhibitor of DNA binding 2 . Biochem Biophys Res Commun. 2016;474:413-20.

68. Ding B, Liu CJ, Huang Y, Yu J, Kong W, Lengyel P. p204 protein overcomes the inhibition of the differentiation of P19 murine embryonal carcinoma cells to beating cardiac myocytes by Id proteins. J Biol Chem. 2006;281: 14893-906.

69. Liu CJ, Ding B, Wang H, Lengyel P. The MyoD-inducible p204 protein overcomes the inhibition of myoblast differentiation by ld proteins. Mol Cell Biol. 2002:22:2893-905.

70. Yates PR, Atherton GT, Deed RW, Norton JD, Sharrocks AD. Id helix-loophelix proteins inhibit nucleoprotein complex formation by the TCF ETSdomain transcription factors. EMBO J. 1999;18:968-76.

71. Inoue T, Shoji W, Obinata M. MIDA1 is a sequence specific DNA binding protein with novel DNA binding properties. Genes Cells. 2000;5:699-709.

72. Shoji W, Inoue T, Yamamoto T, Obinata M. MIDA1, a protein associated with Id, regulates cell growth. J Biol Chem. 1995;270:24818-25.

73. Roberts EC, Deed RW, Inoue T, Norton JD, Sharrocks AD. Id helix-loop-helix proteins antagonize pax transcription factor activity by inhibiting DNA binding. Mol Cell Biol. 2001;21:524-33.

74. Nakajima T, Yageta M, Shiotsu K, Morita K, Suzuki M, Tomooka Y, Oda K. Suppression of adenovirus E1A-induced apoptosis by mutated p53 is overcome by coexpression with Id proteins. Proc Natl Acad Sci U S A. 1998; 95:10590-5

75. Moldes M, Boizard M, Liepvre XL, Feve B, Dugail I, Pairault J. Functional antagonism between inhibitor of DNA binding (Id) and adipocyte determination and differentiation factor $1 /$ sterol regulatory element-binding protein-1c (ADD1/SREBP-1C) trans-factors for the regulation of fatty acid synthase promoter in adipocytes. Biochem J. 1999;344:873-80.

76. Ling MT, Chiu YT, Lee TK, Leung SC, Fung MK, Wang X, Wong KF, Wong YC. Id-1 induces proteasome-dependent degradation of the HBX protein. J Mol Biol. 2008;382:34-43. 
77. Anand G, Yin X, Shahidi AK, Grove L, Prochownik EV. Novel regulation of the helix-loop-helix protein Id1 by S5a, a subunit of the $26 \mathrm{~S}$ proteasome. J Biol Chem. 1997;272:19140-51.

78. Berse $M$, Bounpheng $M$, Huang $X$, Christy B, Pollmann C, Dubiel W. Ubiquitin-dependent degradation of Id 1 and Id 3 is mediated by the COP9 signalosome. J Mol Biol. 2004:343:361-70.

79. Williams SA, Maecker HL, French DM, Liu J, Gregg A, Silverstein LB, Cao TC, Carano RA, Dixit VM. USP1 deubiquitinates ID proteins to preserve a mesenchymal stem cell program in osteosarcoma. Cell. 2011;146:918-30.

80. Zhang X, Ling MT, Wang Q, Lau CK, Leung SC, Lee TK, Cheung AL, Wong YC, Wang X. Identification of a novel inhibitor of differentiation-1 (ID-1) binding partner, caveolin-1, and its role in epithelial-mesenchymal transition and resistance to apoptosis in prostate cancer cells. J Biol Chem. 2007;282: 33284-94.

81. Han W, Wu Z, Zhao Y, Meng Y, Si Y, Yang J, Fu X, Yu L. FHL2 interacts with and acts as a functional repressor of Id 2 in human neuroblastoma cells. Nucleic Acids Res. 2009;37:3996-4009.

82. Lee SB, Frattini V, Bansal M, Castano AM, Sherman D, Hutchinson K, et al. An ID2-dependent mechanism for VHL inactivation in cancer. Nature. 2016;529: 172-7.

83. Chen L, Qiu J, Yang C, Yang X, Chen X, Jiang J, Luo X. Identification of a novel estrogen receptor beta1 binding partner, inhibitor of differentiation-1, and role of ERbeta1 in human breast cancer cells. Cancer Lett. 2009;278: 210-9.

84. Engel I, Murre C. The function of E- and Id proteins in lymphocyte development. Nat Rev Immunol. 2001;1:193-9.

85. Israel MA, Hernandez MC, Florio M, Andres-Barquin PJ, Mantani A, Carter JH, Julin CM. Id gene expression as a key mediator of tumor cell biology. Cancer Res. 1999;59:1726s-30s.

86. Lasorella A, Uo T, lavarone A. Id proteins at the cross-road of development and cancer. Oncogene. 2001;20:8326-33.

87. Ling F, Kang B, Sun XH. Id proteins: small molecules, mighty regulators. Curr Top Dev Biol. 2014;110:189-216.

88. Tzeng SF, de Vellis J. Id1, Id2, and Id3 gene expression in neural cells during development. Glia. 1998;24:372-81.

89. Wang LH, Baker NE. E proteins and ID proteins: Helix-Loop-Helix partners in development and disease. Dev Cell. 2015;35:269-80.

90. Wong YC, Wang X, Ling MT. Id-1 expression and cell survival. Apoptosis. 2004;9:279-89.

91. Yokota Y. Id and development. Oncogene. 2001:20:8290-8.

92. lavarone A, Lasorella A. ID proteins as targets in cancer and tools in neurobiology. Trends Mol Med. 2006;12:588-94.

93. Moeinvaziri F, Shahhoseini M. Epigenetic role of CCAAT box-binding transcription factor NF-Y on ID gene family in human embryonic carcinoma cells. IUBMB Life. 2015;67:880-7.

94. Bain G, Cravatt CB, Loomans C, Alberola-lla J, Hedrick SM, Murre C. Regulation of the helix-loop-helix proteins, E2A and Id3, by the Ras-ERK MAPK cascade. Nat Immunol. 2001;2:165-71

95. Barone MV, Pepperkok R, Peverali FA, Philipson L. Id proteins control growth induction in mammalian cells. Proc Natl Acad Sci U S A. 1994;91:4985-8.

96. Tournay O, Benezra R. Transcription of the dominant-negative helix-loophelix protein Id1 is regulated by a protein complex containing the immediate-early response gene Egr-1. Mol Cell Biol. 1996;16:2418-30.

97. Lin CQ, Singh J, Murata K, Itahana Y, Parrinello S, Liang SH, Gillett CE, Campisi J, Desprez PY. A role for Id-1 in the aggressive phenotype and steroid hormone response of human breast cancer cells. Cancer Res. 2000; 60:1332-40.

98. Villano CM, White LA. Expression of the helix-loop-helix protein inhibitor of DNA binding-1 (ID-1) is activated by all-trans retinoic acid in normal human keratinocytes. Toxicol Appl Pharmacol. 2006;214:219-29.

99. Rotzer D, Krampert M, Sulyok S, Braun S, Stark HJ, Boukamp P, Werner S. Id proteins: novel targets of activin action, which regulate epidermal homeostasis. Oncogene. 2006;25:2070-81.

100. Kee BL, Rivera RR, Murre C. Id3 inhibits B lymphocyte progenitor growth and survival in response to TGF-beta. Nat Immunol. 2001;2:242-7.

101. Sugai M, Gonda H, Kusunoki T, Katakai T, Yokota Y, Shimizu A. Essential role of Id2 in negative regulation of IgE class switching. Nat Immunol. 2003;4 25-30.

102. Korchynskyi O, ten Dijke P. Identification and functional characterization of distinct critically important bone morphogenetic protein-specific response elements in the Id1 promoter. J Biol Chem. 2002;277:4883-91.
103. Lopez-Rovira T, Chalaux E, Massague J, Rosa JL, Ventura F. Direct binding of Smad1 and Smad4 to two distinct motifs mediates bone morphogenetic protein-specific transcriptional activation of Id1 gene. J Biol Chem. 2002;277: 3176-85.

104. Ogata T, Wozney JM, Benezra R, Noda M. Bone morphogenetic protein 2 transiently enhances expression of a gene, Id (inhibitor of differentiation), encoding a helix-loop-helix molecule in osteoblast-like cells. Proc Natl Acad Sci U S A. 1993;90:9219-22

105. Clement JH, Marr N, Meissner A, Schwalbe M, Sebald W, Kliche KO, Hoffken $\mathrm{K}$, Wolfl S. Bone morphogenetic protein 2 (BMP-2) induces sequential changes of Id gene expression in the breast cancer cell line MCF-7. J Cancer Res Clin Oncol. 2000;126:271-9.

106. Langenfeld EM, Kong Y, Langenfeld J. Bone morphogenetic protein 2 stimulation of tumor growth involves the activation of Smad-1/5. Oncogene. 2006;25:685-92.

107. Langenfeld EM, Langenfeld J. Bone morphogenetic protein-2 stimulates angiogenesis in developing tumors. Mol Cancer Res. 2004;2:141-9.

108. Kang Y, Chen CR, Massague J. A self-enabling TGFbeta response coupled to stress signaling: Smad engages stress response factor ATF3 for Id1 repression in epithelial cells. Mol Cell. 2003;11:915-26.

109. Anido J, Saez-Borderias A, Gonzalez-Junca A, Rodon L, Folch G, Carmona MA, et al. TGF-beta receptor inhibitors target the CD44(high)/ld1(high) glioma-initiating cell population in human glioblastoma. Cancer Cell. 2010; 18:655-68.

110. Xu K, Wang L, Feng W, Feng Y, Shu HK. Phosphatidylinositol-3 kinasedependent translational regulation of Id 1 involves the PPM1G phosphatase. Oncogene. 2016;35:5807-16.

111. Fontemaggi G, Dell'Orso S, Trisciuoglio D, Shay T, Melucci E, Fazi F, et al. The execution of the transcriptional axis mutant p53, E2F1 and ID4 promotes tumor neo-angiogenesis. Nat Struct Mol Biol. 2009;16:1086-93.

112. Paolella BR, Havrda MC, Mantani A, Wray CM, Zhang Z, Israel MA. p53 directly represses $1 \mathrm{~d} 2$ to inhibit the proliferation of neural progenitor cells. Stem Cells. 2011;29:1090-101

113. Grcevic D, Kusec R, Kovacic N, Lukic A, Lukic IK, Ivcevic S, et al. Bone morphogenetic proteins and receptors are over-expressed in bone-marrow cells of multiple myeloma patients and support myeloma cells by inducing ID genes. Leuk Res. 2010;34:742-51.

114. Rockman SP, Currie SA, Ciavarella M, Vincan E, Dow C, Thomas RJ, Phillips WA. Id2 is a target of the beta-catenin/T cell factor pathway in colon carcinoma. J Biol Chem. 2001;276:45113-9.

115. Lasorella A, Noseda M, Beyna M, Yokota Y, lavarone A. Id2 is a retinoblastoma protein target and mediates signalling by Myc oncoproteins. Nature. 2000;407:592-8.

116. Swarbrick A, Akerfeldt MC, Lee CS, Sergio CM, Caldon CE, Hunter LJ, Sutherland RL, Musgrove EA. Regulation of cyclin expression and cell cycle progression in breast epithelial cells by the helix-loop-helix protein Id1. Oncogene. 2005;24:381-9.

117. Pillai S, Rizwani W, Li X, Rawal B, Nair S, Schell MJ, Bepler G, Haura E, Coppola D, Chellappan S. ID1 facilitates the growth and metastasis of non-small cell lung cancer in response to nicotinic acetylcholine receptor and epidermal growth factor receptor signaling. Mol Cell Biol. 2011;31:3052-67.

118. Ahlqvist K, Saamarthy K, Syed Khaja AS, Bjartell A, Massoumi R. Expression of Id proteins is regulated by the $\mathrm{BCl}-3$ proto-oncogene in prostate cancer. Oncogene. 2013:32:1601-8.

119. Tam WF, Gu TL, Chen J, Lee BH, Bullinger L, Frohling S, Wang A, Monti S, Golub TR, Gilliland DG. Id1 is a common downstream target of oncogenic tyrosine kinases in leukemic cells. Blood. 2008;112:1981-92.

120. Yu H, Yue X, Zhao Y, Li X, Wu L, Zhang C, et al. LIF negatively regulates tumour-suppressor p53 through Stat3/ID1/MDM2 in colorectal cancers. Nat Commun. 2014;5. doi:10.1038/ncomms6218.

121. Butler DC, Haramizu S, Williamson DL, Alway SE. Phospho-ablated Id2 is growth suppressive and pro-apoptotic in proliferating myoblasts. PLoS One. 2009:4:e6302.

122. Kim NS, Kim HT, Kwon MC, Choi SW, Kim YY, Yoon K, et al. Survival and differentiation of mammary epithelial cells in mammary gland development require nuclear retention of Id2 due to RANK signaling. Mol Cell Biol. 2011; 31:4775-88.

123. Matsumura ME, Lobe DR, MCNamara CA. Contribution of the helix-loophelix factor Id 2 to regulation of vascular smooth muscle cell proliferation. J Biol Chem. 2002;277:7293-7. 
124. Sullivan JM, Havrda MC, Kettenbach AN, Paolella BR, Zhang Z, Gerber SA Israel MA. Phosphorylation regulates Id2 degradation and mediates the proliferation of neural precursor cells. Stem Cells. 2016;34:1321-31.

125. Bounpheng MA, Dimas JJ, Dodds SG, Christy BA. Degradation of Id proteins by the ubiquitin-proteasome pathway. FASEB J. 1999;13:2257-64.

126. Trausch-Azar JS, Lingbeck J, Ciechanover A, Schwartz AL. Ubiquitinproteasome-mediated degradation of Id 1 is modulated by MyoD. J Biol Chem. 2004:279:32614-9.

127. Deed RW, Armitage S, Norton JD. Nuclear localization and regulation of Id protein through an E protein-mediated chaperone mechanism. J Biol Chem. 1996;271:23603-6.

128. Ghil SH, Jeon YJ, Suh-Kim H. Inhibition of BETA2/NeuroD by Id2. Exp Mol Med. 2002;34:367-73.

129. Makita J, Kurooka H, Mori K, Akagi Y, Yokota Y. Identification of the nuclear export signal in the helix-loop-helix inhibitor Id1. FEBS Lett. 2006;580:1812-6.

130. Pagliuca A, Gallo P, De Luca P, Lania L. Class A helix-loop-helix proteins are positive regulators of several cyclin-dependent kinase inhibitors' promoter activity and negatively affect cell growth. Cancer Res. 2000;60:1376-82.

131. Ohtani N, Zebedee Z, Huot TJ, Stinson JA, Sugimoto M, Ohashi Y, Sharrocks $A D$, Peters $G$, Hara E. Opposing effects of Ets and Id proteins on p16INK4a expression during cellular senescence. Nature. 2001;409:1067-70.

132. Hara E, Yamaguchi T, Nojima H, Ide T, Campisi J, Okayama H, Oda K. Idrelated genes encoding helix-loop-helix proteins are required for $\mathrm{G} 1$ progression and are repressed in senescent human fibroblasts. J Biol Chem. 1994;269:2139-45.

133. Peverali FA, Ramqvist T, Saffrich R, Pepperkok R, Barone MV, Philipson L. Regulation of $\mathrm{G} 1$ progression by E2A and Id helix-loop-helix proteins. EMBO J. 1994;13:4291-301.

134. Prabhu S, Ignatova A, Park ST, Sun XH. Regulation of the expression of cyclin-dependent kinase inhibitor p21 by E2A and Id proteins. Mol Cell Biol. 1997:17:5888-96.

135. Alani RM, Young AZ, Shifflett CB. Id1 regulation of cellular senescence through transcriptional repression of p16/Ink4a. Proc Natl Acad Sci U S A. 2001;98:7812-6.

136. Smialowski $P$, Singh M, Mikolajka A, Majumdar S, Joy JK, Nalabothula N, Krajewski M, Degenkolbe R, Bernard HU, Holak TA. NMR and mass spectrometry studies of putative interactions of cell cycle proteins $\mathrm{pRb}$ and CDK6 with cell differentiation proteins MyoD and ID-2. Biochim Biophys Acta. 2005;1750:48-60

137. Ouyang XS, Wang $X$, Ling MT, Wong HL, Tsao SW, Wong YC. Id-1 stimulates serum independent prostate cancer cell proliferation through inactivation of p16(INK4a)/pRB pathway. Carcinogenesis. 2002;23:721-5.

138. Qian Y, Chen X. ID1, inhibitor of differentiation/DNA binding, is an effector of the p53-dependent DNA damage response pathway. J Biol Chem. 2008; 283:22410-6.

139. Chong JL, Wenzel PL, Saenz-Robles MT, Nair V, Ferrey A, Hagan JP, et al. E2f1-3 switch from activators in progenitor cells to repressors in differentiating cells. Nature. 2009:462:930-4.

140. Ling MT, Wang X, Ouyang XS, Lee TK, Fan TY, Xu K, Tsao SW, Wong YC. Activation of MAPK signaling pathway is essential for Id-1 induced serum independent prostate cancer cell growth. Oncogene. 2002;21:8498-505.

141. Perk J, lavarone A, Benezra R. Id family of helix-loop-helix proteins in cancer. Nat Rev Cancer. 2005;5:603-14.

142. Bedford L, Walker R, Kondo T, van Cruchten I, King ER, Sablitzky F. Id4 is required for the correct timing of neural differentiation. Dev Biol. 2005;280: 386-95.

143. Hacker C, Kirsch RD, Ju XS, Hieronymus T, Gust TC, Kuhl C, et al. Transcriptional profiling identifies Id 2 function in dendritic cell development. Nat Immunol. 2003:4:380-6.

144. Pan L, Sato S, Frederick JP, Sun XH, Zhuang Y. Impaired immune responses and B-cell proliferation in mice lacking the Id3 gene. Mol Cell Biol. 1999;19: 5969-80.

145. Rivera RR, Johns CP, Quan J, Johnson RS, Murre C. Thymocyte selection is regulated by the helix-loop-helix inhibitor protein, Id3. Immunity. 2000;12:17-26.

146. Volpert OV, Pili R, Sikder HA, Nelius T, Zaichuk T, Morris C, Shiflett CB, Devlin MK, Conant K, Alani RM. Id1 regulates angiogenesis through transcriptional repression of thrombospondin-1. Cancer Cell. 2002;2:473-83.

147. Yokota Y, Mansouri A, Mori S, Sugawara S, Adachi S, Nishikawa S, Gruss P. Development of peripheral lymphoid organs and natural killer cells depends on the helix-loop-helix inhibitor Id2. Nature. 1999;397:702-6.
148. Yun K, Mantani A, Garel S, Rubenstein J, Israel MA. Id4 regulates neural progenitor proliferation and differentiation in vivo. Development. 2004;131: 5441-8.

149. Lyden D, Young AZ, Zagzag D, Yan W, Gerald W, O'Reilly R, et al. Id1 and Id 3 are required for neurogenesis, angiogenesis and vascularization of tumour xenografts. Nature. 1999;401:670-7.

150. Ellmeier W, Weith A. Expression of the helix-loop-helix gene Id3 during murine embryonic development. Dev Dyn. 1995;203:163-73.

151. Evans SM, O'Brien TX. Expression of the helix-loop-helix factor Id during mouse embryonic development. Dev Biol. 1993;159:485-99.

152. Jen Y, Manova K, Benezra R. Each member of the Id gene family exhibits a unique expression pattern in mouse gastrulation and neurogenesis. Dev Dyn. 1997;208:92-106.

153. Andres-Barquin PJ, Hernandez MC, Israel MA. Id genes in nervous system development. Histol Histopathol. 2000;15:603-18.

154. Neuman T, Keen A, Zuber MX, Kristjansson Gl, Gruss P, Nornes HO. Neuronal expression of regulatory helix-loop-helix factor ld2 gene in mouse. Dev Biol. 1993;160:186-95.

155. Rothschild G, Zhao X, lavarone A, Lasorella A. E proteins and Id2 converge on p57Kip2 to regulate cell cycle in neural cells. Mol Cell Biol. 2006:26:4351-61.

156. Wu Y, Richard J-P, Wang SD, Rath P, Laterra J, Xia S. Regulation of glioblastoma multiforme stem-like cells by inhibitor of DNA binding proteins and oligodendroglial lineage-associated transcription factors. Cancer Sci. 2012;103. doi:10.1111/j.349-7006.2012.02260.x.

157. Tzeng SF. Inhibitors of DNA binding in neural cell proliferation and differentiation. Neurochem Res. 2003;28:45-52.

158. Chen XS, Zhang YH, Cai QY, Yao ZX. ID2: A negative transcription factor regulating oligodendroglia differentiation. J Neurosci Res. 2012;90:925-32.

159. Fancy SP, Kotter MR, Harrington EP, Huang JK, Zhao C, Rowitch DH, Franklin RJ. Overcoming remyelination failure in multiple sclerosis and other myelin disorders. Exp Neurol. 2010:225:18-23.

160. Peddada S, Yasui DH, LaSalle JM. Inhibitors of differentiation (ID1, ID2, ID3 and ID4) genes are neuronal targets of MeCP2 that are elevated in Rett syndrome. Hum Mol Genet. 2006;15:2003-14.

161. Bohrer C, Pfurr S, Mammadzada K, Schildge S, Plappert L, Hils M, et al. The balance of Id 3 and $E 47$ determines neural stem/precursor cell differentiation into astrocytes. EMBO J. 2015:34:2804-19.

162. Bain G, Quong MW, Soloff RS, Hedrick SM, Murre C. Thymocyte maturation is regulated by the activity of the helix-loop-helix protein, E47. J Exp Med. 1999;190:1605-16.

163. Quong MW, Harris DP, Swain SL, Murre C. E2A activity is induced during Bcell activation to promote immunoglobulin class switch recombination. EMBO J. 1999;18:6307-18.

164. Saisanit S, Sun XH. A novel enhancer, the pro-B enhancer, regulates Id1 gene expression in progenitor B cells. Mol Cell Biol. 1995;15:1513-21.

165. Wilson RB, Kiledjian M, Shen CP, Benezra R, Zwollo P, Dymecki SM, Desiderio SV, Kadesch T. Repression of immunoglobulin enhancers by the helix-loophelix protein Id: implications for B-lymphoid-cell development. Mol Cell Biol. 1991;11:6185-91.

166. Kim D, Peng XC, Sun XH. Massive apoptosis of thymocytes in T-cell-deficient Id1 transgenic mice. Mol Cell Biol. 1999;19:8240-53.

167. Ji M, Li H, Suh HC, Klarmann KD, Yokota Y, Keller JR, Id2 intrinsically regulates lymphoid and erythroid development via interaction with different target proteins. Blood. 2008:112:1068-77.

168. Nakatsukasa $H$, Zhang D, Maruyama T, Chen H, Cui K, Ishikawa M, et al. The DNA-binding inhibitor Id3 regulates IL-9 production in CD4+ T cells. Nat Immunol. 2015;16:1077-84

169. Goldfarb AN, Flores JP, Lewandowska K. Involvement of the E2A basic helixloop-helix protein in immunoglobulin heavy chain class switching. Mol Immunol. 1996;33:947-56.

170. Cannarile MA, Lind NA, Rivera R, Sheridan AD, Camfield KA, Wu BB, Cheung KP, Ding Z, Goldrath AW. Transcriptional regulator Id2 mediates CD8+ T cell immunity. Nat Immunol. 2006;7:1317-25.

171. Masson F, Ghisi M, Groom JR, Kallies A, Seillet C, Johnstone RW, Nutt SL, Belz GT. Id2 represses E2A-mediated activation of IL-10 expression in T cells. Blood. 2014;123:3420-8.

172. Papaspyridonos M, Matei I, Huang Y, do Rosario Andre M, Brazier-Mitouart $\mathrm{H}$, Waite JC, et al. Id1 suppresses anti-tumour immune responses and promotes tumour progression by impairing myeloid cell maturation. Nat Commun. 2015;6. doi:10.1038/ncomms7840. 
173. Desprez PY, Hara E, Bissell MJ, Campisi J. Suppression of mammary epithelial cell differentiation by the helix-loop-helix protein Id-1. Mol Cell Biol. 1995;15: 3398-404.

174. Parrinello S, Lin CQ, Murata K, Itahana Y, Singh J, Krtolica A, Campisi J, Desprez PY. Id-1, ITF-2, and Id-2 comprise a network of helix-loop-helix proteins that regulate mammary epithelial cell proliferation, differentiation, and apoptosis. J Biol Chem. 2001;276:39213-9.

175. Mori S, Nishikawa SI, Yokota Y. Lactation defect in mice lacking the helixloop-helix inhibitor Id2. EMBO J. 2000;19:5772-81.

176. Dong J, Huang SX, Caikovski M, Ji SQ, McGrath A, Custorio MG, et al. ID4 regulates mammary gland development by suppressing p38MAPK activity. Development. 2011;138:5247-56.

177. Langlands K, Down GA, Kealey T. Id proteins are dynamically expressed in normal epidermis and dysregulated in squamous cell carcinoma. Cancer Res. 2000;60:5929-33.

178. Chen Y-S, Aubee J, DiVito KA, Zhou H, Zhang W, Chou F-P, Simbulan-Rosenthal CM, Rosenthal DS. Id3 induces an Elk-1-caspase-8-dependent apoptotic pathway in squamous carcinoma cells. Cancer Med. 2015;4:914-24.

179. Schaefer BM, Koch J, Wirzbach A, Kramer MD. Expression of the helix-loophelix protein ID1 in keratinocytes is upregulated by loss of cell-matrix contact. Exp Cell Res. 2001;266:250-9.

180. Bjorntorp E, Parsa R, Thornemo M, Wennberg AM, Lindahl A. The helix-loophelix transcription factor Id 1 is highly expressed in psoriatic involved skin. Acta Derm Venereol. 2003;83:403-9.

181. Peng Y, Kang Q, Luo Q, Jiang W, Si W, Liu BA, et al. Inhibitor of DNA binding/differentiation helix-loop-helix proteins mediate bone morphogenetic protein-induced osteoblast differentiation of mesenchymal stem cells. J Biol Chem. 2004;279:32941-9.

182. Lee J, Kim K, Kim JH, Jin HM, Choi HK, Lee SH, et al. Id helix-loop-helix proteins negatively regulate TRANCE-mediated osteoclast differentiation. Blood. 2006;107:2686-93

183. Oh J, Lee MS, Yeon JT, Choi SW, Kim HS, Shim H, et al. Inhibitory regulation of osteoclast differentiation by interleukin-3 via regulation of c-Fos and Id protein expression. J Cell Physiol. 2012;227:1851-60.

184. Kim HJ, Hong JM, Yoon KA, Kim N, Cho DW, Choi JY, Lee IK, Kim SY. Early growth response 2 negatively modulates osteoclast differentiation through upregulation of Id helix-loop-helix proteins. Bone. 2012;51:643-50.

185. Benezra R. The Id proteins: targets for inhibiting tumor cells and their blood supply. Biochim Biophys Acta. 2001;1551:F39-47.

186. Sun L, Trausch-Azar JS, Ciechanover A, Schwartz AL. Ubiquitinproteasome-mediated degradation, intracellular localization, and protein synthesis of MyoD and Id1 during muscle differentiation. J Biol Chem. 2005;280:26448-56.

187. Buitenhuis M, van Deutekom HW, Verhagen LP, Castor A, Jacobsen SE, Lammers JW, Koenderman L, Coffer PJ. Differential regulation of granulopoiesis by the basic helix-loop-helix transcriptional inhibitors Id1 and Id2. Blood. 2005:105:4272-81.

188. Jankovic V, Ciarrocchi A, Boccuni P, DeBlasio T, Benezra R, Nimer SD. Id1 restrains myeloid commitment, maintaining the self-renewal capacity of hematopoietic stem cells. Proc Natl Acad Sci U S A. 2007;104:1260-5.

189. Nakashima K, Takizawa T, Ochiai W, Yanagisawa M, Hisatsune T, Nakafuku M, Miyazono K, Kishimoto T, Kageyama R, Taga T. BMP2-mediated alteration in the developmental pathway of fetal mouse brain cells from neurogenesis to astrocytogenesis. Proc Natl Acad Sci U S A. 2001;98:5868-73.

190. Nam HS, Benezra R. High levels of Id1 expression define B1 type adult neural stem cells. Cell Stem Cell. 2009;5:515-26.

191. Ying QL, Nichols J, Chambers I, Smith A. BMP induction of Id proteins suppresses differentiation and sustains embryonic stem cell self-renewal in collaboration with STAT3. Cell. 2003;115:281-92.

192. Jung S, Park RH, Kim S, Jeon YJ, Ham DS, Jung MY, Kim SS, Lee YD, Park CH, Suh-Kim H. Id proteins facilitate self-renewal and proliferation of neural stem cells. Stem Cells Dev. 2010;19:831-41.

193. Niola F, Zhao X, Singh D, Castano A, Sullivan R, Lauria M, et al. Id proteins synchronize stemness and anchorage to the niche of neural stem cells. Nat Cell Biol. 2012;14:477-87.

194. Bai G, Sheng N, Xie Z, Bian W, Yokota Y, Benezra R, Kageyama R, Guillemot $F$, Jing N. Id sustains Hes 1 expression to inhibit precocious neurogenesis by releasing negative autoregulation of Hes1. Dev Cell. 2007;13:283-97.

195. Park HJ, Hong M, Bronson RT, Israel MA, Frankel WN, Yun K. Elevated Id2 expression results in precocious neural stem cell depletion and abnormal brain development. Stem Cells. 2013;31:1010-21.
196. Kumar D, Shadrach JL, Wagers AJ, Lassar AB. Id3 is a direct transcriptional target of Pax7 in quiescent satellite cells. Mol Biol Cell. 2009;20:3170-7.

197. Jin X, Yin J, Kim SH, Sohn YW, Beck S, Lim YC, Nam DH, Choi YJ, Kim H. EGFRAKT-Smad signaling promotes formation of glioma stem-like cells and tumor angiogenesis by ID3-driven cytokine induction. Cancer Res. 2011;71:7125-34.

198. Shin D-H, Park J-H, Lee J-Y, Won H-Y, Jang K-S, Min K-W, Jang S-H, Woo J-K, Oh SH, Kong G. Overexpression of Id1 in transgenic mice promotes mammary basal stem cell activity and breast tumorigenesis. Oncotarget. 2015;6:17276-90.

199. Richter J, Schlesner M, Hoffmann S, Kreuz M, Leich E, Burkhardt B, et al. Recurrent mutation of the ID3 gene in Burkitt lymphoma identified by integrated genome, exome and transcriptome sequencing. Nat Genet. 2012; 44:1316-20.

200. Ding Y, Wang G, Ling MT, Wong YC, Li X, Na Y, Zhang X, Chua CW, Wang X, Xin D. Significance of Id-1 up-regulation and its association with EGFR in bladder cancer cell invasion. Int J Oncol. 2006;28:847-54.

201. Fong S, Debs RJ, Desprez PY. Id genes and proteins as promising targets in cancer therapy. Trends Mol Med. 2004;10:387-92.

202. Liu P, Liu S, Qi H, Li Y, He H, Wei F. Effects of silencing Id-1 in cell culture of human adenoid cystic carcinoma. Oral Oncol. 2009;45:783-8.

203. Schindl M, Oberhuber G, Obermair A, Schoppmann SF, Karner B, Birner P. Overexpression of $\mathrm{Id}-1$ protein is a marker for unfavorable prognosis in early-stage cervical cancer. Cancer Res. 2001;61:5703-6.

204. Schoppmann SF, Schindl M, Bayer G, Aumayr K, Dienes J, Horvat R, Rudas M, Gnant M, Jakesz R, Birner P. Overexpression of Id-1 is associated with poor clinical outcome in node negative breast cancer. Int J Cancer. 2003;104:677-82.

205. Hasskarl J, Duensing S, Manuel E, Munger K. The helix-loop-helix protein ID1 localizes to centrosomes and rapidly induces abnormal centrosome numbers. Oncogene. 2004;23:1930-8.

206. Hasskarl J, Mern DS, Munger K. Interference of the dominant negative helixloop-helix protein ID1 with the proteasomal subunit S5A causes centrosomal abnormalities. Oncogene. 2008;27:1657-64.

207. Manthey C, Mern DS, Gutmann A, Zielinski AJ, Herz C, Lassmann S, Hasskarl $J$. Elevated endogenous expression of the dominant negative basic helixloop-helix protein ID1 correlates with significant centrosome abnormalities in human tumor cells. BMC Cell Biol. 2010;11. doi:10.1186/1471-2121-11-2.

208. Desprez PY, Lin CQ, Thomasset N, Sympson CJ, Bissell MJ, Campisi J. A novel pathway for mammary epithelial cell invasion induced by the helixloop-helix protein Id-1. Mol Cell Biol. 1998;18:4577-88.

209. Fong S, Itahana Y, Sumida T, Singh J, Coppe JP, Liu Y, et al. Id-1 as a molecular target in therapy for breast cancer cell invasion and metastasis. Proc Natl Acad Sci U S A. 2003;100:13543-8.

210. Raida M, Clement JH, Leek RD, Ameri K, Bicknell R, Niederwieser D, Harris $\mathrm{AL}$. Bone morphogenetic protein 2 (BMP-2) and induction of tumor angiogenesis. J Cancer Res Clin Oncol. 2005;131:741-50.

211. Itahana Y, Singh J, Sumida T, Coppe JP, Parrinello S, Bennington JL, Desprez PY. Role of Id-2 in the maintenance of a differentiated and noninvasive phenotype in breast cancer cells. Cancer Res. 2003;63:7098-105.

212. Stighall M, Manetopoulos C, Axelson H, Landberg G. High ID2 protein expression correlates with a favourable prognosis in patients with primary breast cancer and reduces cellular invasiveness of breast cancer cells. Int J Cancer. 2005;115:403-11.

213. Zhou $Y$, Ming J, $X u$ Y, Zhang $Y$, Jiang J. ERbeta1 inhibits the migration and invasion of breast cancer cells through upregulation of E-cadherin in a Id 1dependent manner. Biochem Biophys Res Commun. 2015;457:141-7.

214. Lee JY, Kang MB, Jang SH, Qian T, Kim HJ, Kim CH, Kim Y, Kong G. Id-1 activates Akt-mediated Wnt signaling and p27(Kip1) phosphorylation through PTEN inhibition. Oncogene. 2009;28:824-31.

215. Coppe JP, Itahana Y, Moore DH, Bennington JL, Desprez PY. Id-1 and Id-2 proteins as molecular markers for human prostate cancer progression. Clin Cancer Res. 2004;10:2044-51.

216. Asirvatham AJ, Schmidt MA, Chaudhary J. Non-redundant inhibitor of differentiation (Id) gene expression and function in human prostate epithelial cells. Prostate. 2006;66:921-35.

217. Carey JP, Asirvatham AJ, Galm O, Ghogomu TA, Chaudhary J. Inhibitor of differentiation $4(\mathrm{Id} 4)$ is a potential tumor suppressor in prostate cancer. BMC Cancer. 2009;9. doi:10.1186/1471-2407-9-173.

218. Ling MT, Wang X, Lee DT, Tam PC, Tsao SW, Wong YC. Id-1 expression induces androgen-independent prostate cancer cell growth through activation of epidermal growth factor receptor (EGF-R). Carcinogenesis. 2004:25:517-25. 
219. Ling MT, Wang $X$, Zhang $X$, Wong YC. The multiple roles of Id-1 in cancer progression. Differentiation. 2006;74:481-7.

220. Zielinski AJ, Fong S, Allison J, Kawahara M, Coppe JP, Feiler H, Lee NM, Desprez PY. The helix-loop-helix Id-1 inhibits PSA expression in prostate cancer cells. Int J Cancer. 2010;126:2490-6.

221. Sharma P, Patel D, Chaudhary J. Id 1 and Id 3 expression is associated with increasing grade of prostate cancer: Id3 preferentially regulates CDKN1B. Cancer Med. 2012;1:187-97.

222. Chinaranagari S, Sharma P, Chaudhary J. EZH2 dependent H3K27me3 is involved in epigenetic silencing of ID4 in prostate cancer. Oncotarget. 2014; 5:7172-82.

223. Patel D, Knowell AE, Korang-Yeboah M, Sharma P, Joshi J, Glymph S, et al, Inhibitor of differentiation 4 (ID4) inactivation promotes de novo steroidogenesis and castration-resistant prostate cancer. Mol Endocrinol. 2014;28:1239-53.

224. Komaragiri SK, Bostanthirige DH, Morton DJ, Patel D, Joshi J, Upadhyay S, Chaudhary J. ID4 promotes AR expression and blocks tumorigenicity of PC3 prostate cancer cells. Biochem Biophys Res Commun. 2016;478:60-6.

225. Yuen HF, Chua CW, Chan YP, Wong YC, Wang X, Chan KW. Id proteins expression in prostate cancer: high-level expression of Id- 4 in primary prostate cancer is associated with development of metastases. Mod Pathol. 2006;19:931-41.

226. Li J, Xie L, Gan X, Liu B, Zhang Y, Song B, Lin Y, Hu L. Association of inhibitor of differentiation 1 expression with human papillomaviruses infections in cervical carcinoma. Int J Gynecol Cancer. 2011;21:1276-81.

227. Ciarrocchi A, Piana S, Valcavi R, Gardini G, Casali B. Inhibitor of DNA binding1 induces mesenchymal features and promotes invasiveness in thyroid tumour cells. Eur J Cancer. 2011;47:934-45.

228. Sun W, Guo MM, Han P, Lin JZ, Liang FY, Tan GM, Li HB, Zeng M, Huang XM. Id-1 and the p65 subunit of NF-kappaB promote migration of nasopharyngeal carcinoma cells and are correlated with poor prognosis. Carcinogenesis. 2012:33:810-7.

229. O'Brien CA, Kreso A, Ryan P, Hermans KG, Gibson L, Wang Y, Tsatsanis A, Gallinger S, Dick JE. ID1 and ID3 regulate the self-renewal capacity of human colon cancer-initiating cells through p21. Cancer Cell. 2012; 21:777-92.

230. Zhang X, Ai F, Li X, She X, Li N, Tang A, et al. Inflammation-induced S100A8 activates Id3 and promotes colorectal tumorigenesis. Int J Cancer. 2015;137: 2803-14.

231. Wang Q, Tsao SW, Fu S, Xue W, Meng X, Feng H, Wong YC, Wang X. Overexpression of Id-1 in gastric adenocarcinoma: implication for a novel diagnostic marker. Anticancer Res. 2004;24:881-6.

232. Sharma BK, Kolhe R, Black SM, Keller JR, Mivechi NF, Satyanarayana A. Inhibitor of differentiation 1 transcription factor promotes metabolic reprogramming in hepatocellular carcinoma cells. FASEB J. 2016;30:262-75.

233. Matsuda Y, Yamagiwa S, Takamura M, Honda Y, Ishimoto Y, Ichida T, Aoyagi Y. Overexpressed Id-1 is associated with a high risk of hepatocellular carcinoma development in patients with cirrhosis without transcriptional repression of p16. Cancer. 2005;104:1037-44.

234. Kleeff J, Ishiwata T, Friess H, Buchler MW, Israel MA, Korc M. The helix-loophelix protein Id2 is overexpressed in human pancreatic cancer. Cancer Res. 1998;58:3769-72.

235. Lee KT, Lee YW, Lee JK, Choi SH, Rhee JC, Paik SS, Kong G. Overexpression of Id-1 is significantly associated with tumour angiogenesis in human pancreas cancers. Br J Cancer. 2004;90:1198-203.

236. Rahme GJ, Israel MA. Id4 suppresses MMP2-mediated invasion of glioblastoma-derived cells by direct inactivation of Twist1 function. Oncogene. 2015;34:53-62.

237. Elias MC, Tozer KR, Silber JR, Mikheeva S, Deng M, Morrison RS, et al. TWIST is Expressed in Human Gliomas, Promotes Invasion. Neoplasia. 2005;7:824-37.

238. Mikheeva SA, Mikheev AM, Petit A, Beyer R, Oxford RG, Khorasani L, et al. TWIST1 promotes invasion through mesenchymal change in human glioblastoma. Mol Cancer. 2010;9. doi:10.1186/1476-4598-9-194.

239. Vandeputte DAA, Troost D, Leenstra S, ljlst-Keizers H, Ramkema M, Bosch DA, Baas F, Das NK, Aronica E. Expression and distribution of id helix-loophelix proteins in human astrocytic tumors. Glia. 2002;38:329-38.

240. Zhao Z, He H, Wang C, Tao B, Zhou H, Dong Y, et al. Downregulation of Id2 increases chemosensitivity of glioma. Tumor Biol. 2015;36:4189-96.

241. Guo P, Lan J, Ge J, Mao Q, Qiu Y. ID1 regulates U87 human cell proliferation and invasion. Oncol Lett. 2013;6:921-6.
242. Barrett Lindy E, Granot Z, Coker C, lavarone A, Hambardzumyan D, Holland Eric C, Nam H-s, Benezra R. Self-Renewal Does Not Predict Tumor Growth Potential in Mouse Models of High-Grade Glioma. Cancer Cell. 2012;21:11-24.

243. Niola F, Zhao X, Singh D, Sullivan R, Castano A, Verrico A, et al. Mesenchymal high-grade glioma is maintained by the ID-RAP1 axis. J Clin Investig. 2013;123:405-17.

244. Maris JM, Matthay KK. Molecular biology of neuroblastoma. J Clin Oncol. 1999:17:2264-79.

245. Lasorella A, Boldrini R, Dominici C, Donfrancesco A, Yokota Y, Inserra A, lavarone A. Id2 is critical for cellular proliferation and is the oncogenic effector of N-myc in human neuroblastoma. Cancer Res. 2002;62:301-6.

246. Alaminos M, Gerald WL, Cheung N-KV. Prognostic value of MYCN and ID2 overexpression in neuroblastoma. Pediatr Blood Cancer. 2005;45:909-15.

247. Vandesompele J, Edsjo A, De Preter K, Axelson H, Speleman F, Pahlman S. ID2 expression in neuroblastoma does not correlate to MYCN levels and lacks prognostic value. Oncogene. 2003:22:456-60.

248. Sato Y, Kobayashi Y, Sasaki H, Toyama T, Kondo S, Kiriyama M, Fujii Y. Expression of Id2 mRNA in neuroblastoma and normal ganglion. Eur I Surg Oncol. 2003;29:284-7.

249. Wang Q, Hii G, Shusterman S, Mosse Y, Winter CL, Guo C, Zhao H, Rappaport E, Hogarty MD, Maris JM. ID2 expression is not associated with MYCN amplification or expression in human neuroblastomas. Cancer Res. 2003;63:1631-5.

250. Gebauer S, Yu AL, Omura-Minamisawa M, Batova A, Diccianni MB. Expression profiles and clinical relationships of ID2, CDKN1B, and CDKN2A in primary neuroblastoma. Genes Chromosomes Cancer. 2004;41:297-308.

251. Murphy DJ, Swigart LB, Israel MA, Evan GI. Id2 is dispensable for Mycinduced epidermal neoplasia. Mol Cell Biol. 2004;24:2083-90.

252. Nilsson JA, Nilsson LM, Keller U, Yokota Y, Boyd $K$, Cleveland JL. Id 2 is dispensable for myc-induced lymphomagenesis. Cancer Res. 2004;64:7296-301.

253. Chakrabarti L, Abou-Antoun T, Vukmanovic S, Sandler A. Reversible adaptive plasticity: A mechanism for neuroblastoma cell heterogeneity and chemoresistance. Frontiers Oncol. 2012;2. doi:10.3389/fonc.2012.00082.

254. Chakrabarti L, Wang B-D, Lee NH, Sandler AD. A mechanism linking Id2TGF $\beta$ crosstalk to reversible adaptive plasticity in neuroblastoma. PLoS One. 2013;8:e83521

255. Snyder AD, Dulin-Smith AN, Houston RH, Durban AN, Brisbin BJ, Oostra TD, Marshall JT, Kahwash BM, Pierson CR. Expression pattern of Id proteins in medulloblastoma. Pathol Oncol Res. 2013;19:437-46.

256. May AM, Frey A-V, Bogatyreva L, Benkisser-Petersen M, Hauschke D, Lübbert M, Wäsch R, Werner M, Hasskarl J, Lassmann S. ID2 and ID3 protein expression mirrors granulopoietic maturation and discriminates between acute leukemia subtypes. Histochem Cell Biol. 2014;141:431-40.

257. Suh HC, Leeanansaksiri W, Ji M, Klarmann KD, Renn K, Gooya J, et al. Id1 immortalizes hematopoietic progenitors in vitro and promotes a myeloproliferative disease in vivo. Oncogene. 2008;27:5612-23.

258. Tang R, Hirsch P, Fava F, Lapusan S, Marzac C, Teyssandier I, Pardo J, Marie $J P$, Legrand $\mathrm{O}$. High Id1 expression is associated with poor prognosis in 237 patients with acute myeloid leukemia. Blood. 2009;114:2993-3000.

259. Ghisi M, Kats L, Masson F, Li J, Kratina T, Vidacs E, et al. Id2 and E proteins orchestrate the initiation and maintenance of MLL-rearranged acute myeloid leukemia. Cancer Cell. 2016;30:59-74.

260. Kang H, Wang X, Gao L, Cen J, Li M, Wang W, Wang N, Li Y, Wang L, Yu L. Clinical implications of the quantitative detection of ID4 gene methylation in myelodysplastic syndrome. Eur J Med Res. 2015;20:16-26.

261. Weiler S, Ademokun JA, Norton JD. ID helix-loop-helix proteins as determinants of cell survival in B-cell chronic lymphocytic leukemia cells in vitro. Mol Cancer. 2015;14:30-50.

262. Wang XR, Kang HY, Cen J, Li YH, Wang LL, Yu L. Methylation status of id4 gene promoter in patients with chronic myeloid leukemia. J Exp Hematol. 2010;18:1402-4.

263. Chen SS, Claus R, Lucas DM, Yu L, Qian J, Ruppert AS, et al. Silencing of the inhibitor of DNA binding protein 4 (ID4) contributes to the pathogenesis of mouse and human CLL. Blood. 2011:117:862-71.

264. Renne C, Martin-Subero Jl, Eickernjager M, Hansmann ML, Kuppers R, Siebert $\mathrm{R}$, Brauninger A. Aberrant expression of ID2, a suppressor of B-cell-specific gene expression, in Hodgkin's lymphoma. Am J Pathol. 2006;169:655-64.

265. Cen J, Shen JL, Wang XR, Kang HY, Wang LL, Sun L, Li YH, Yu L. Association between lymphoma prognosis and aberrant methylation of ID4 and ZO-1 in bone marrow and paraffin-embedded lymphoma tissues of treatmentnaive patients. Oncol Rep. 2013;30:455-61. 
266. Hagiwara K, Nagai H, Li Y, Ohashi H, Hotta T, Saito H. Frequent DNA methylation but not mutation of the ID4 gene in malignant lymphoma. J Clin Exp Hematop. 2007;47:15-8.

267. Schmitz R, Young RM, Ceribelli M, Jhavar S, Xiao W, Zhang M, et al. Burkitt lymphoma pathogenesis and therapeutic targets from structural and functional genomics. Nature. 2012;490:116-20.

268. Yu L, Liu C, Vandeusen J, Becknell B, Dai Z, Wu YZ, et al. Global assessment of promoter methylation in a mouse model of cancer identifies ID4 as a putative tumor-suppressor gene in human leukemia. Nat Genet. 2005;37:265-74.

269. Gao XZ, Zhao WG, Wang GN, Cui MY, Zhang YR, Li WC. Inhibitor of DNA binding 4 functions as a tumor suppressor and is targetable by 5-aza-2'deoxycytosine with potential therapeutic significance in Burkitt's lymphoma. Mol Med Rep. 2016:13:1269-74.

270. Umetani N, Takeuchi H, Fujimoto A, Shinozaki M, Bilchik AJ, Hoon DSB. E pigenetic inactivation of ID4 in colorectal carcinomas correlates with poor differentiation and unfavorable prognosis. Clin Cancer Res. 2004;10:7475-83.

271. Noetzel E, Veeck J, Niederacher D, Galm O, Horn F, Hartmann A, Knuchel R, Dahl E. Promoter methylation-associated loss of ID4 expression is a marker of tumour recurrence in human breast cancer. BMC Cancer. 2008;8. doi:10.1186/1471-2407-8-154.

272. Chan ASW, Tsui WY, Chen X, Chu KM, Chan TL, Chan ASY, Li R, So S, Yuen ST, Leung SY. Downregulation of ID4 by promoter hypermethylation in gastric adenocarcinoma. Oncogene. 2003;22:6946-53.

273. Dell'Orso S, Ganci F, Strano S, Blandino G, Fontemaggi G. ID4: a new player in the cancer arena. Oncotarget. 2010;1:48-58.

274. Zhang YH, Zhang B, Fang J, Cao XC. Hypomethylation of DNA-binding inhibitor 4 serves as a potential biomarker in distinguishing acquired tamoxifen-refractory breast cancer. Int J Clin Exp Pathol. 2015;8:9500-5.

275. DeBerardinis RJ, Lum JJ, Hatzivassiliou G, Thompson CB. The biology of cancer: Metabolic reprogramming fuels cell growth and proliferation. Cell Metab. 2008;7:11-20.

276. Yoshida GJ. Metabolic reprogramming: the emerging concept and associated therapeutic strategies. J Exp Clin Cancer Res. 2015;34 doi:10.1186/s13046-015-0221-y.

277. Gao P, Tchernyshyov I, Chang TC, Lee YS, Kita K, Ochi T, et al. c-Myc suppression of miR-23a/b enhances mitochondrial glutaminase expression and glutamine metabolism. Nature. 2009;458:762-5.

278. Minn AJ, Gupta GP, Siegel PM, Bos PD, Shu W, Giri DD, Viale A, Olshen AB, Gerald WL, Massague J. Genes that mediate breast cancer metastasis to lung. Nature. 2005;436:518-24.

279. Zigler M, Villares GJ, Dobroff AS, Wang H, Huang L, Braeuer RR, et al. Expression of Id-1 is regulated by MCAM/MUC18: a missing link in melanoma progression. Cancer Res. 2011;71:3494-504.

280. Gumireddy K, Li A, Gimotty PA, Klein-Szanto AJ, Showe LC, Katsaros D, Coukos G, Zhang L, Huang Q. KLF17 is a negative regulator of epithelialmesenchymal transition and metastasis in breast cancer. Nat Cell Biol. 2009;11:1297-304

281. Bielenberg DR, Hida Y, Shimizu A, Kaipainen A, Kreuter M, Kim CC, Klagsbrun M. Semaphorin 3F, a chemorepulsant for endothelial cells, induces a poorly vascularized, encapsulated, nonmetastatic tumor phenotype. J Clin Invest. 2004;114:1260-71.

282. Coma S, Amin DN, Shimizu A, Lasorella A, lavarone A, Klagsbrun M. Id2 promotes tumor cell migration and invasion through transcriptional repression of semaphorin 3F. Cancer Res. 2010;70:3823-32.

283. Dong H-J, Jang G-B, Lee H-Y, Park S-R, Kim J-Y, Nam J-S, Hong I-S. The Wnt/ $\beta$-catenin signaling/ld2 cascade mediates the effects of hypoxia on the hierarchy of colorectal-cancer stem cells. Sci Rep. 2016;6. doi:10.1038/ srep22966.

284. Brabletz T. To differentiate or not-routes towards metastasis. Nat Rev Cancer. 2012:12:425-36.

285. Stankic M, Pavlovic S, Chin Y, Brogi E, Padua D, Norton L, Massague J, Benezra R. TGF $\beta$-Id1 signaling opposes Twist1 and promotes metastatic colonization via a mesenchymal-to-epithelial transition. Cell Rep. 2013;5: 1228-42.

286. Teo WS, Nair R, Swarbrick A. New insights into the role of ID proteins in breast cancer metastasis: a MET affair. Breast Cancer Res. 2014;16. doi:10.1186/bcr3654

287. Lehne G. P-glycoprotein as a drug target in the treatment of multidrug resistant cancer. Curr Drug Targets. 2000;1:85-99.

288. Kim R, Emi M, Tanabe K, Toge T. Therapeutic potential of antisense Bcl-2 as a chemosensitizer for cancer therapy. Cancer. 2004;101:2491-502.
289. Davis JM, Navolanic PM, Weinstein-Oppenheimer CR, Steelman LS, Hu W, Konopleva M, Blagosklonny MV, McCubrey JA. Raf-1 and Bcl-2 induce distinct and common pathways that contribute to breast cancer drug resistance. Clin Cancer Res. 2003;9:1161-70.

290. Nakanishi C, Toi M. Nuclear factor-kappaB inhibitors as sensitizers to anticancer drugs. Nat Rev Cancer. 2005;5:297-309.

291. Vasilevskaya I, O'Dwyer PJ. Role of Jun and Jun kinase in resistance of cancer cells to therapy. Drug Resist Updat. 2003;6:147-56.

292. Ling MT, Wang X, Ouyang XS, Xu K, Tsao SW, Wong YC. Id-1 expression promotes cell survival through activation of NF-kappaB signalling pathway in prostate cancer cells. Oncogene. 2003;22:4498-508.

293. Kashiwakura Y, Ochiai K, Watanabe M, Abarzua F, Sakaguchi M, Takaoka M, Tanimoto R, Nasu Y, Huh NH, Kumon H. Down-regulation of inhibition of differentiation-1 via activation of activating transcription factor 3 and Smad regulates REIC/Dickkopf-3-induced apoptosis. Cancer Res. 2008;68:8333-41.

294. Cheung HW, Ling MT, Tsao SW, Wong YC, Wang X. Id-1-induced Raf/MEK pathway activation is essential for its protective role against taxol-induced apoptosis in nasopharyngeal carcinoma cells. Carcinogenesis. 2004;25:881-7.

295. Kim H, Chung H, Kim HJ, Lee JY, Oh MY, Kim Y, Kong G. Id-1 regulates Bcl-2 and Bax expression through p53 and NF-kappaB in MCF-7 breast cancer cells. Breast Cancer Res Treat. 2008;112:287-96.

296. Zhang X, Ling MT, Wang X, Wong YC. Inactivation of Id-1 in prostate cancer cells: A potential therapeutic target in inducing chemosensitization to taxol through activation of JNK pathway. Int J Cancer. 2006;118:2072-81.

297. Wong YC, Zhang XM, Ling MT, Wang XH. Inactivation of ID-1 gene induces sensitivity of prostate cancer cells to chemotherapeutic drugs. Adv Exp Med Biol. 2008;617:565-72.

298. Lin JC, Chang SY, Hsieh DS, Lee CF, Yu DS. The association of Id-1, MIF and GSTpi with acquired drug resistance in hormone independent prostate cancer cells. Oncol Rep. 2005;13:983-8.

299. Hu H, Han HY, Wang YL, Zhang XP, Chua CW, Wong YC, Wang XF, Ling MT, $X u K X$. The role of Id-1 in chemosensitivity and epirubicin-induced apoptosis in bladder cancer cells. Oncol Rep. 2009;21:1053-9.

300. Zhang X, Ling MT, Wong YC, Wang X. Evidence of a novel antiapoptotic factor: Role of inhibitor of differentiation or DNA binding (ld-1) in anticancer drug- induced apoptosis. Cancer Sci. 2007;98:308-14.

301. Zhao YH, Luo AP, Li S, Zhang W, Chen HY, Li Y, Ding F, Huang FR, Liu $\mathrm{ZH}$. Inhibitor of differentiation/DNA binding 1 (ID1) inhibits etoposideinduced apoptosis in a c-Jun/c-Fos-dependent manner. J Biol Chem. 2016:291:6831-42.

302. Li B, Xu WW, Guan XY, Qin YR, Law S, Lee NPY, et al. Competitive binding between Id1 and E2F1 to Cdc20 regulates E2F1 degradation and thymidylate synthase expression to promote esophageal cancer chemoresistance. Clin Cancer Res. 2016;22:1243-55.

303. Tsunedomi R, lizuka N, Harada S, Oka M. Susceptibility of hepatoma-derived cells to histone deacetylase inhibitors is associated with ID2 expression. Int Oncol. 2013:42:1159-66

304. Jeon HM, Sohn YW, Oh SY, Kim SH, Beck S, Kim S. ID4 imparts chemoresistance and cancer stemness to glioma cells by derepressing miR9(star)-mediated suppression of SOX2. Cancer Res. 2011;71:3410-21.

305. de Candia P, Solit DB, Giri D, Brogi E, Siegel PM, Olshen AB, Muller WJ, Rosen N, Benezra R. Angiogenesis impairment in Id-deficient mice cooperates with an Hsp90 inhibitor to completely suppress HER2/neudependent breast tumors. Proc Natl Acad Sci U S A. 2003;100:12337-42.

306. Chen Z, Liu S, Sumida T, Sun S, Wei Y, Liu M, Dong Z, Zhang F, Hamakawa $H$, Wei F. Silencing Id-1 with RNA interference inhibits adenoid cystic carcinoma in mice. J Surg Res. 2011;169:57-66.

307. Henke E, Perk J, Vider J, de Candia P, Chin Y, Solit DB, et al. Peptideconjugated antisense oligonucleotides for targeted inhibition of a transcriptional regulator in vivo. Nat Biotechnol. 2008;26:91-100.

308. Annibali D, Gioia U, Savino M, Laneve P, Caffarelli E, Nasi S. A new module in neural differentiation control: two microRNAs upregulated by retinoic acid, miR-9 and -103, target the differentiation inhibitor ID2. PLoS One. 2012;7:e40269.

309. McAllister SD, Christian RT, Horowitz MP, Garcia A, Desprez PY. Cannabidiol as a novel inhibitor of $1 \mathrm{~d}-1$ gene expression in aggressive breast cancer cells. Mol Cancer Ther. 2007;6:2921-7.

310. Murase R, Sumida T, Kawamura R, Onishi-Ishikawa A, Hamakawa $H_{\text {, }}$ McAllister SD, Desprez PY. Suppression of invasion and metastasis in aggressive salivary cancer cells through targeted inhibition of ID1 gene expression. Cancer Lett. 2016;377:11-6. 
311. Soroceanu L, Murase R, Limbad C, Singer E, Allison J, Adrados I, et al. Id-1 is a key transcriptional regulator of glioblastoma aggressiveness and a novel therapeutic target. Cancer Res. 2013;73:1559-69.

312. Tada K, Kawahara K, Matsushita S, Hashiguchi T, Maruyama I, Kanekura T. MK615, a Prunus mume Steb. Et Zucc ('Ume') extract, attenuates the growth of A375 melanoma cells by inhibiting the ERK1/2-ld-1 pathway. Phytother Res. 2012;26:833-8

313. Yu XL, Jing T, Zhao H, Li PJ, Xu WH, Shang FF. Curcumin inhibits expression of inhibitor of DNA binding 1 in PC3 cells and xenografts. Asian Pac J Cancer Prev. 2014;15:1465-70.

314. Tsang CM, Cheung KCP, Cheung YC, Man K, Lui WW-Y, Tsao SW, Feng Y. Berberine suppresses $I d-1$ expression and inhibits the growth and development of lung metastases in hepatocellular carcinoma. Biochim Biophys Acta. 2015;1852:541-51.

315. Wang P, Zhang L, Yao J, Shi Y, Li P, Ding K. An arabinogalactan from flowers of Panax notoginseng inhibits angiogenesis by BMP2/Smad/ld1 signaling. Carbohydr Polym. 2015;121:328-35.

316. Huh Jl, Calvo A, Charles R, Green JE. Distinct tumor stage-specific inhibitory effects of 2-methoxyestradiol in a breast cancer mouse model associated with Id-1 expression. Cancer Res. 2006;66:3495-503.

317. Jang TJ, Jung $\mathrm{KH}$, Choi EA. Id-1 gene downregulation by sulindac sulfide and its upregulation during tumor development in gastric cancer. Int J Cancer. 2006;118:1356-63.

318. Ma J, Shi M, Li G, Wang N, Wei J, Wang T, Ma J, Wang Y. Regulation of Id1 expression by epigallocatechin-3-gallate and its effect on the proliferation and apoptosis of poorly differentiated AGS gastric cancer cells. Int J Oncol. 2013;43:1052-8.

319. Rahme GJ, Zhang ZH, Young AL, Cheng C, Bivona EJ, Fiering SN, Hitoshi Y, Israel MA. PDGF engages an E2F-USP1 signaling pathway to support ID2mediated survival of proneural glioma cells. Cancer Res. 2016;76:2964-76.

320. Gautschi O, Tepper CG, Purnell PR, Izumiya Y, Evans CP, Green TP, et al. Regulation of Id1 expression by SRC: implications for targeting of the bone morphogenetic protein pathway in cancer. Cancer Res. 2008;68:2250-8.

321. Hao L, Liao Q, Tang Q, Deng H, Chen L. Id-1 promotes osteosarcoma cell growth and inhibits cell apoptosis via PI3KJAKT signaling pathway. Biochem Biophys Res Commun. 2016;470:643-9.

322. Langenfeld E, Deen M, Zachariah E, Langenfeld J. Small molecule antagonist of the bone morphogenetic protein type I receptors suppresses growth and expression of Id 1 and Id 3 in lung cancer cells expressing Oct4 or nestin. Mol Cancer. 2013;12:129-44.

323. Chaudhary J, Johnson J, Kim G, Skinner MK. Hormonal regulation and differential actions of the helix-loop-helix transcriptional inhibitors of differentiation (Id1, Id2, Id3, and Id4) in Sertoli cells. Endocrinology. 2001; 142:1727-36.

324. Garland W, Benezra R, Chaudhary J. Targeting protein-protein interactions to treat cancer-recent progress and future directions. Annu Rep Med Chem. 2013:48:227-45

325. Mern DS, Hasskarl J, Burwinkel B. Inhibition of Id proteins by a peptide aptamer induces cell-cycle arrest and apoptosis in ovarian cancer cells. Br J Cancer. 2010;103:1237-44.

326. Mern DS, Hoppe-Seyler K, Hoppe-Seyler F, Hasskarl J, Burwinkel B. Targeting Id1 and Id3 by a specific peptide aptamer induces E-box promoter activity, cell cycle arrest, and apoptosis in breast cancer cells. Breast Cancer Res Treat. 2010;124:623-33.

327. Ciarapica R, Annibali D, Raimondi L, Savino M, Nasi S, Rota R. Targeting Id protein interactions by an engineered HLH domain induces human neuroblastoma cell differentiation. Oncogene. 2009;28:1881-91.

328. Ciarapica R, Rosati J, Cesareni G, Nasi S. Molecular recognition in helix-loophelix and helix-loop-helix-leucine zipper domains. Design of repertoires and selection of high affinity ligands for natural proteins. J Biol Chem. 2003;278: 12182-90.

329. Chen CH, Kuo SC, Huang LJ, Hsu MH, Lung FD. Affinity of synthetic peptide fragments of MyoD for Id 1 protein and their biological effects in several cancer cells. J Pept Sci. 2010;16:231-41.

330. Pellegrino S, Ferri N, Colombo N, Cremona E, Corsini A, Fanelli R, Gelmi ML, Cabrele C. Synthetic peptides containing a conserved sequence motif of the Id protein family modulate vascular smooth muscle cell phenotype. Bioorg Med Chem Lett. 2009;19:6298-302.

331. Chakrabarti L, Morgan C, Sandler AD. Combination of Id 2 knockdown whole tumor cells and checkpoint blockade: A potent vaccine strategy in a mouse neuroblastoma model. PLoS One. 2015;10:e0129237.
332. Korang-Yeboah M, Patel D, Morton D, Sharma P, Gorantla Y, Joshi J, Nagappan P, Pallaniappan R, Chaudhary J. Intra-tumoral delivery of functional ID4 protein via PCL/maltodextrin nano-particle inhibits prostate cancer growth. Oncotarget. 2016;7:68072-85.

333. Murre C. Helix-loop-helix proteins and lymphocyte development. Nat Immunol. 2005;6:1079-86.

334. Naya FJ, Stellrecht CM, Tsai MJ. Tissue-specific regulation of the insulin gene by a novel basic helix-loop-helix transcription factor. Genes Dev. 1995;9:1009-19.

335. Lo LC, Johnson JE, Wuenschell CW, Saito T, Anderson DJ. Mammalian achaetescute homolog 1 is transiently expressed by spatially restricted subsets of early neuroepithelial and neural crest cells. Genes Dev. 1991:5:1524-37.

336. Meierhans D, el-Ariss C, Neuenschwander M, Sieber M, Stackhouse JF, Allemann RK. DNA binding specificity of the basic-helix-loop-helix protein MASH-1. Biochemistry. 1995;34:11026-36.

337. Firulli BA, Hadzic DB, McDaid JR, Firulli AB. The basic helix-loop-helix transcription factors dHAND and eHAND exhibit dimerization characteristics that suggest complex regulation of function. J Biol Chem. 2000;275:33567-73.

338. Castanon I, Baylies MK. A Twist in fate: evolutionary comparison of Twist structure and function. Gene. 2002;287:11-22.

339. Ayer DE, Kretzner L, Eisenman RN. Mad: a heterodimeric partner for Max that antagonizes Myc transcriptional activity. Cell. 1993;72:211-22.

340. Hurlin PJ, Queva C, Koskinen PJ, Steingrimsson E, Ayer DE, Copeland NG Jenkins NA, Eisenman RN. Mad3 and Mad4: novel Max-interacting transcriptional repressors that suppress c-myc dependent transformation and are expressed during neural and epidermal differentiation. EMBO J. 1995;14:5646-59.

341. Zervos AS, Gyuris J, Brent R. Mxi1, a protein that specifically interacts with Max to bind Myc-Max recognition sites. Cell. 1993;72:223-32.

342. Blackwood EM, Eisenman RN. Max: a helix-loop-helix zipper protein that forms a sequence-specific DNA-binding complex with Myc. Science. 1991; 251:1211-7.

343. Lasorella A, Benezra R, lavarone A. The ID proteins: master regulators of cancer stem cells and tumour aggressiveness. Nat Rev Cancer. 2014;14:77-91.

344. Aloia L, Gutierrez A, Caballero JM, Di Croce L. Direct interaction between Id1 and Zrf1 controls neural differentiation of embryonic stem cells. EMBO Rep. 2015; 16:63-70

345. Inoue T, Shoji W, Obinata M. MIDA1, an Id-associating protein, has two distinct DNA binding activities that are converted by the association with Id1: a novel function of Id protein. Biochem Biophys Res Commun. 1999; 266:147-51.

\section{Submit your next manuscript to BioMed Central and we will help you at every step:}

- We accept pre-submission inquiries

- Our selector tool helps you to find the most relevant journal

- We provide round the clock customer support

- Convenient online submission

- Thorough peer review

- Inclusion in PubMed and all major indexing services

- Maximum visibility for your research

Submit your manuscript at www.biomedcentral.com/submit 